\title{
Some Properties of Porcelains and Phase Relations in the Ternary Systems of Beryllia and Zirconia With Titania, Ceria, and Chromia
}

\author{
S. M. Lang, R. S. Roth, and C. L. Fillmore ${ }^{1}$
}

\begin{abstract}
The following physical properties were determined for some $\mathrm{BeO}-\mathrm{TiO}_{2}-\mathrm{ZrO}_{2}$ and $\mathrm{BeO}$ $\mathrm{CeO}_{2}-\mathrm{ZrO}_{2}$ porcelain specimens of less than 0.10 percent equivalent water absorption: Maturing range, $1,450^{\circ}$ to $1,750^{\circ} \mathrm{C}$; shrinkage, 13.9 to 18.7 percent; bulk density, 3.0 to 5.8 $\mathrm{g} / \mathrm{cm}^{3}$; room-temperature sonic elastic properties-Young's modulus, 18.7 to $43.6 \times 10^{6}$ $\mathrm{lb} /$ in. ${ }^{2}$, shear modulus, 8.0 to $18.1 \times 10^{6} \mathrm{lb} / \mathrm{in}^{2}$, Poisson's ratio, 0.17 to 0.28 , and bulk modulus, 5.3 to $12.1 \times 10^{6} \mathrm{lb} / \mathrm{in} .^{2}$ - for each specimen tested for transverse strength; room-temperature static strength properties-transverse, 12.0 to $23.4 \times 10^{3} \mathrm{lb} / \mathrm{in}^{2}$, and compressive, 112 to $271 \times 10^{3} \mathrm{lb} /$ in. $^{2}$ - and Young's modulus, 18.7 to $46.8 \times 10^{6} \mathrm{lb} / \mathrm{in}^{2}$; and, at $1,800^{\circ} \mathrm{F}$ $\left(982^{\circ} \mathrm{C}\right)$, static transverse strength, 9.1 to $18.1 \times 10^{3} \mathrm{lb} / \mathrm{in}^{2}$, Young's modulus, 21.5 to 38.3 $\times 10^{6} \mathrm{lb} / \mathrm{in.}^{2}$, and strain rates under various stresses. Because of the loss of chromia from the samples during preliminary heating trials, no specimens of $\mathrm{BeO}-\mathrm{Cr}_{2} \mathrm{O}_{3}-\mathrm{ZrO}_{2}$ mixtures were prepared for these tests. The conjecture is made that porous oxide porcelains with requisite strength properties may prove of considerable interest in the search for materials of greater thermal-shock resistance than that associated with dense, practically impervious oxide porcelains with high-strength properties.

It is proposed that the phase diagram of the $\mathrm{BeO}-\mathrm{TiO}_{2}-\mathrm{ZrO}_{2}$ system includes an invariant point at about $20-\mathrm{BeO}, 35-\mathrm{TiO}_{2}$, and $45-\mathrm{ZrO}_{2}\left(\right.$ wt $\%$ ) and $1,630^{\circ} \mathrm{C}$; an invariant point at about $20-\mathrm{BeO}, 55-\mathrm{TiO}_{2}$, and $25-\mathrm{ZrO}_{2}(\mathrm{wt} \%)$ and $1,610^{\circ} \mathrm{C}$; and primary crystallization fields of $\mathrm{BeO}$, tetragonal $\mathrm{ZrO}_{2}$ solid solution, $\mathrm{ZrO}_{2} \cdot \mathrm{TiO}_{2}$ solid solution, and $\mathrm{TiO}_{2}$ solid solution.

The limited X-ray data indicate that the $\mathrm{BeO}-\mathrm{CeO}_{2}-\mathrm{ZrO}_{2}$ system is a simple one with an invariant point at approximately $40-\mathrm{BeO}, 30-\mathrm{CeO}_{2}$, and $30-\mathrm{Z}_{\mathrm{rO}}$ (wt \%) and $1,845^{\circ} \mathrm{C}$, and primary crystallization fields of $\mathrm{BeO}$, tetragonal $\mathrm{ZrO}_{2}$ solid solution, and $\mathrm{CeO}_{2}$ solid solution.

Based upon extremely limited data and considerable amount of speculation, a suggested configuration of the liquidus surfaces of the $\mathrm{BeO}-\mathrm{Cr}_{2} \mathrm{O}_{3}-\mathrm{ZrO}_{2}$ system would be one that contains three invariant points and primary crystallization fields of $\mathrm{BeO}$, tetragonal $\mathrm{Z} \mathrm{rO}_{2}, \mathrm{BeO} \cdot \mathrm{Cr}_{2} \mathrm{O}_{3}, \mathrm{BeO} \cdot 3 \mathrm{Cr}_{2} \mathrm{O}_{3}$, and $\mathrm{Cr}_{2} \mathrm{O}_{3}$. Beryllium chromate $\left(\mathrm{BeO} \cdot \mathrm{Cr}_{2} \mathrm{O}_{3}\right.$ ), the chromia analog of chrysoberyl, was identified; crystallographic parameters of this orthorhombic compound were tentatively determined as being $a=10.0 \mathrm{~A}, b=3.8 \mathrm{~A}$, and $c=4.5 \mathrm{~A}$.
\end{abstract}

\section{Introduction}

Many investigations have been conducted, and many reports published, on special oxide ceramics to replace metals for high-temperature service. Although no completely acceptable ceramics have been developed for such a critical use as turbine blades, the need is so urgent that continued research is justified.

Previous work at the National Bureau of Standards $[1,2,3,4]^{2}$ on the properties of pure oxides, singly and in combination, shows that the best ceramics for use under severe service conditions usually involve combinations of $\mathrm{BeO}$ and $\mathrm{ZrO}_{2}$, due in large part to the apparent thermal conductivity of beryllia and to the strength of zirconia. In order to produce impervious specimens, required to attain reproducibility of maximum strength test values, it is necessary to introduce at least a third component to beryllia-zirconia mixtures.

This report describes exploratory physical-property studies for mixtures in the systems $\mathrm{BeO}-\mathrm{TiO}_{2}-$ $\mathrm{ZrO}, 2, \mathrm{BeO}-\mathrm{CeO}_{2}-\mathrm{ZrO}_{2}$, and $\mathrm{BeO}-\mathrm{Cr}_{2} \mathrm{O}_{3}-\mathrm{ZrO}_{2}$. In addition, a limited investigation was conducted to determine the approximate equilibrium relations that exist in these systems.

${ }^{1}$ Formerly, a National Bureau of Standards staff member

2 Figures in brackets indicate the literature references at the end of this paper.

\section{Materials, Equipment, and Procedures}

Commercially available materials of high purity were used in the preparation of all specimens: beryllia $(\mathrm{BeO})$, low-calcined material of nominal 99.7 percent purity; titania $\left(\mathrm{TiO}_{2}\right)$, TAM "Titanox A-MO", nominal titania content 98.7 percent, calcined at $1,100^{\circ} \mathrm{C}$; ceria $\left(\mathrm{CeO}_{2}\right)$, calcined material of nominal $99+$ percent purity; chromia $\left(\mathrm{Cr}_{2} \mathrm{O}_{3}\right)$, chemically pure reagent-grade material; and zirconia $\left(\mathrm{ZrO}_{2}\right)$, low-calcined material of nominal 99-percent purity, recalcined at $1,440^{\circ} \mathrm{C}$. As prepared for use, the materials were, in all instances, sufficiently finely divided to pass the No. 325 U. S. Standard Sieve.

For convenience, the test procedures employed $[2,3,4]$ are given briefly. Carbon tetrachloride was used for absorption determinations, and the results were converted to equivalent water-absorption values. Matured bodies were considered to be those having less than 0.1 percent of equivalent water absorption. Shrinkage values were calculated from micrometer measurements before and after heating. Apparent density values were obtained by calculations based upon the volume as determined by a mercury volumeter and the dry weight of the specimen. A few calculated bulk density values were obtained from. the dry weight of the samples by measuring the length, width, and breadth of specimens specifically prepared for transverse-strength tests. The ends 
of the $1 / 2$-in.-diameter specinens for the compressivestrength tests were ground parallel, so that the height-to-diameter ratio was approximately 2 . The test pieces were placed between graphite-oil lubricated, cold-rolled steel blocks, and the compressive stress was applied at about $31,250 \mathrm{lb} / \mathrm{in}^{2} / \mathrm{min}$ by a 75,000 lb-capacity hydraulic press.

Transverse moduli of rupture and of elasticity were determined statically at room temperature and at $1,800^{\circ} \mathrm{F}\left(982^{\circ} \mathrm{C}\right)$, using a specially designed transverse-strength tes furnace [3]. The specimens were stressed at 2 -min intervals at calculated increments of $1,500 \mathrm{lb} / \mathrm{in}^{2}$. When it was noted, during the $1,800^{\circ} \mathrm{F}$ tests, that the deflection following loading continued after the first minute, it was assumed that permanent deformation, or "plastic flow," had occurred. This deformation could be verified when the test pieces were examined for permanent curvature following rupture. In order to investigate the relative magnitude of the deformation, some bars were subjected to a short-time $(1 \mathrm{hr})$ stress-strain test at $1,800^{\circ} \mathrm{F}$. Beginning at $6,000-\mathrm{lb} / \mathrm{in}^{2}$ calculated stress, stress increments of $1,500 \mathrm{lb} / \mathrm{in}^{2}$ were added to the bars at hourly intervals, or until rupture occurred, during which time the deflection was measured at prescribed intervals.

This paper is believed to be the first in which the room temperature elastic properties, Young's modulus, shear modulus, Poisson's ratio, and bulk modulus, are reported for each of a series of porcelain-type specimens. The prepared transverse-test specimens and equipment recently developed [5] were used for these tests. Young's modulus values were calculated, using the flexural vibration frequencies determined along the width and depth of the bars and, in a few instances, longitudinally through the length. In most cases, the values obtained for sound bars were within one-half percent of each other and were always within 1 percent. Where internal flaws, such as cracks, were present, the variations obtained were large. Shear modulus values were calculated, using the determined torsional vibration frequencies. Poisson's ratio and the bulk modulus were calculated for each specimen by the formulas:

$$
\begin{aligned}
\sigma & =\frac{E}{2 G}-1 \\
K & =\frac{E}{3(1+\sigma)},
\end{aligned}
$$

where $\sigma$ is Poisson's ratio, $E$ is Young's modulus, $G$ is the shear modulus, and $K$ is the bulk modulus.

The reported phase relations for the three systems were determined mainly by interpreting X-ray diffraction patterns of the interiors of some of the maturing range and transverse-strength test specimens. Liquidus surface configurations were obtained by isothermal tests of mixtures at various temperature levels. A few melting-point and softening-range determinations were made. It was assumed that the published equilibrium relations of the various subordinate binary systems were correct. Because of the nature of the investigation, it was not deemed advisable to determine any phase relations in anything more than an approximate manner.

Assignment of mole ratios to the various mixtures ${ }^{3}$ is used solely because a compound will nearly always correspond to an integral molecular ratio. If sufficient mole-ratio mixtures are heated, the chances of missing a compound are minimized, regardless of the investigational procedure employed.

\section{The System $\mathrm{BeO}-\mathrm{TiO}_{2}-\mathrm{ZrO}_{2}$}

\subsection{Phase Relations}

\section{a. The System $\mathrm{BeO}-\mathrm{TiO}_{2}$}

The equilibria were described by von Wartenberg et al. [6] as including two compounds, $3 \mathrm{BeO} \cdot \mathrm{TiO}_{2}$ and $\mathrm{BeO} \cdot \mathrm{TiO}_{2}$, melting congruently at $1,800^{\circ}$ and $1,720^{\circ} \mathrm{C}$, respectively. In the work at NBS [4] no evidence was found of a compound in this system. A single eutectic exists at about 85 weight percent of $\mathrm{TiO}_{2}$ and $1,670^{\circ} \mathrm{C}$, and a narrow region of $\mathrm{TiO}_{2}$ $\mathrm{BeO}$ solid solution extends from just beyond the eutectic at about 90 weight percent of $\mathrm{TiO}_{2}$ to pure $\mathrm{TiO}_{2}$. The absence of compound formation is supported by the results of a limited study at Pennsylvania State College ]7], which also indicate that a solid solution may exist at high temperatures.

\section{b. The System $\mathrm{BeO}-\mathrm{ZrO}_{2}$}

It was first proposed [8] that this is a simple system with one eutectic at about $2,180^{\circ} \mathrm{C}$ and 65 weight percent of $\mathrm{ZrO}_{2}$. The compound $3 \mathrm{BeO} \cdot 2 \mathrm{ZrO}_{2}$, melting at $2,550^{\circ} \mathrm{C}$, and two eutectics were then reported [9]; but later [10], the system was shown as a simple one with the eutectic at about 75 weight percent of $\mathrm{ZrO}_{2}$ and $2,240^{\circ} \mathrm{C}$. Similar data, placing the eutectic at $2,210^{\circ} \mathrm{C}$, were published the same year [11], and a diagram again showing the $3 \mathrm{~B} \cdot 2 \mathrm{Z}$ compound was published in 1933 [12]. In 1937 von Wartenberg et al. [6] reported a single, sharp eutectic at about 66 mole percent of $\mathrm{BeO}$ and $2,200^{\circ}$ C. Mixtures of $\mathrm{ZrO}_{2}$ and $\mathrm{BeO}$ for use in crucibles were discussed by Ryschkewitsch [13]. In the work at NBS, Geller et al. [1] found no evidence of a compound between $\mathrm{BeO}$ and $\mathrm{ZrO}_{2}$.

\section{c. The System $\mathrm{TiO}_{-}-\mathrm{ZrO}_{2}$}

The melting relations were reported by von Wartenberg and Gurr [10] as indicating one eutectic at about 20 mole $(27.8 \mathrm{wt})$ percent of $\mathrm{ZrO}_{2}$ and $1,760^{\circ}$ C. Vaporization was insignificant, but they reported considerable reduction of $\mathrm{TiO}_{2}$, so that the diagram obtained was not strictly that between $\mathrm{ZrO}_{2}$ and $\mathrm{TiO}_{2}$. A limited study by Bussem, Schusterius, and Ungewiss [14] indicated no compound formation but some solid-solution development. They showed that 10 weight percent of zirconia at $1,460^{\circ}$, and 16 weight percent at $1,520^{\circ} \mathrm{C}$, may dissolve in the rutile structure without change. The system was found by Sowman and Andrews [15] to be one of partial solid solutions with no inter-

3 The short form of indicating the mole compositions of mixtures is used throughout the text. The code is $\mathrm{B}=\mathrm{BeO}, \mathrm{Ti}=\mathrm{TiO}_{2}, \mathrm{Ce}=\mathrm{CeO}_{2}, \mathrm{Cr}=\mathrm{Cr}_{2} \mathrm{O}_{3}$ and $\mathrm{Z}=\mathrm{ZrO}_{2}$. The short form, i. e., $1 \mathrm{~B}: 2 \mathrm{Ti}: 3 \mathrm{Z}$, then reads: 1 mole of $\mathrm{BeO}$ plus 2 moles of $\mathrm{TiO}_{2}$ plus 3 moles of $\mathrm{ZrO}_{2}$ and does not indicate a compound. 
mediate compounds and the eutectic to be located at 50 to 55 weight percent of $\mathrm{ZrO}_{2}$ and about $1,600^{\circ} \mathrm{C}$. At this temperature the maximum solubility of $\mathrm{ZrO}_{2}$ in $\mathrm{TiO}_{2}$ was found to be 21 weight percent; that of $\mathrm{TiO}_{2}$ in $\mathrm{ZrO}_{2}$ was found to be 37 weight percent. A peritectic was indicated at 60 weight percent of $\mathrm{ZrO}_{2}$ and $1,900^{\circ} \mathrm{C}$ between cubic zirconia and a tetragonal zirconia solid solution. Later work by Sowman [16] indicated that the 1:1 mixture, after heat treatment, consists of either a distorted form of tetragonal zirconia or a new compound. Brown and Duwez $[17,18]$ proposed a diagram indicating the existence of the $\mathrm{ZrO}_{2} \cdot \mathrm{TiO}_{2}$ compound. Independently, Coughanour, Roth, and DeProsse [19] located and described the optical and X-ray properties of the incongruently melting 1:1 compound. Their diagram shows a eutectic at about 80 mole $(72.2 \mathrm{wt})$ percent of $\mathrm{TiO}_{2}$ and $1,760^{\circ} \mathrm{C}$ and an invariant point at about 55 mole $(44.2 \mathrm{wt})$ percent of $\mathrm{TiO}_{2}$ and $1,820^{\circ} \mathrm{C}$. Solid solutions are formed at the eutectic temperature in which about 15 mole percent of $\mathrm{ZrO}_{2}$ (at $78.6 \mathrm{wt}$ percent of $\mathrm{TiO}_{2}$ ) will enter the rutile structure and about 10 mole percent of $\mathrm{TiO}_{2}$ (at $49.3 \mathrm{wt}$ percent of $\mathrm{TiO}_{2}$ ) will enter the compound structure. There was no reaction of the tetragonal zirconia solid solution with the compound. At the invariant point temperature $\left(1,820^{\circ} \mathrm{C}\right)$, the melting data indicate that about 38 mole $(28.4 \mathrm{wt})$ percent of $\mathrm{TiO}_{2}$ forms a solid solution with tetragonal zirconia. Although not shown on the diagram, it was found that about 10 mole $(6.7 \mathrm{wt})$ percent of $\mathrm{TiO}_{2}$ forms a solid solution with monoclinic zirconia.

\section{d. The System BeO-TiO $-\mathrm{ZrO}_{2}$}

No literature references could be found describing the phase relations for this system. In the present study, some ternary mixtures were successively heated at $1,600^{\circ}, 1,625^{\circ}, 1,650^{\circ}, 1,675^{\circ}, 1,750^{\circ}$, and $1,800^{\circ} \mathrm{C}$ for $30 \mathrm{~min}$ at each temperature and were visually examined after each heating for evidences of melting. Petrographic and X-ray diffraction examinations were made using a few fused samples.

Mixture $4 \mathrm{~B}: 4 \mathrm{Ti}: 1 \mathrm{Z}$, which melts at about $1,615^{\circ}$ $\pm 10 \mathrm{deg} \mathrm{C}$, appears to be located near the probable eutectic composition. No ternary compounds were found to exist, and the system contains primary crystallization fields for $\mathrm{BeO}$, tetragonal $\mathrm{ZrO}_{2}$ solid solution, $\mathrm{TiO}_{2}$ solid solution, and $\mathrm{ZrO}_{2} \cdot \mathrm{TiO}_{2}$ solid solution, this probably being small. These data are shown on figure 1.

Figure 2 shows an isothermal section based upon X-ray examinations of specimens that had been heated at $1,550^{\circ} \mathrm{C}$ during the maturing range tests. Each sample was sectioned so that an interior surface could be used to prepare the X-ray diffraction patterns. Within the firing-time interval used for these specimens, the solid-state reactions seem to attain an equilibrium condition in all compositions throughout the ternary system. However, when samples of a few mixtures at or near the binary join were melted during the tests to determine liquidus surface, equilibrium was not attained. The diffraction patterns show four instead of three phases

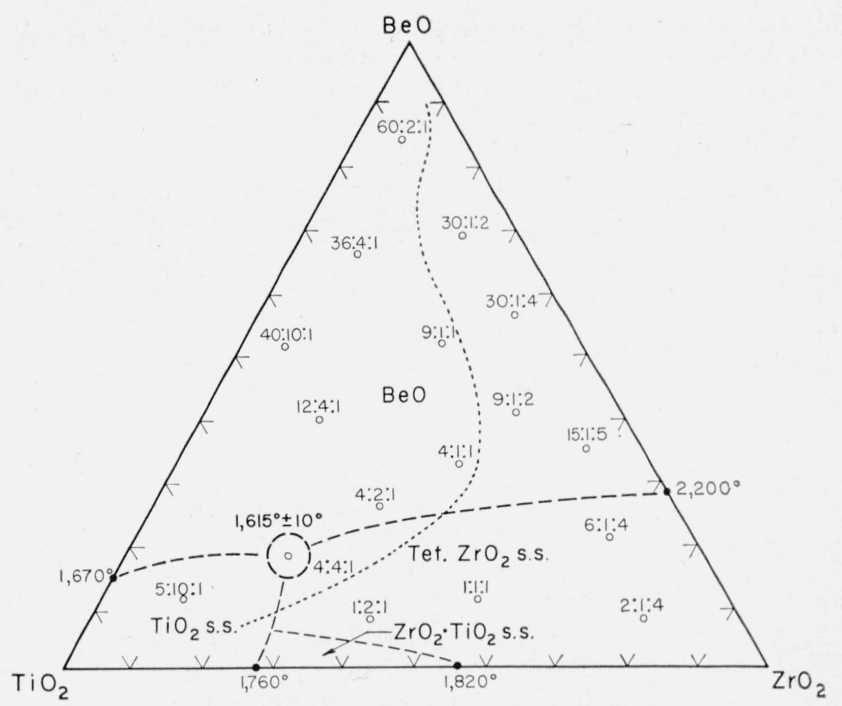

Figure 1. The system $\mathrm{BeO}-\mathrm{TiO}_{2}-\mathrm{ZrO}_{2}$.

This figure shows the approximate location and temperature of the invariant point and the probable phase boundaries. Compositions of the mixtures are indicated on the figure in molar ratios but are placed graphically according to weight percentages. All of the mixtures, whose compositions are located between the heavy-dash line and the $\mathrm{BeO}-\mathrm{TiO}_{2}$ join, could be matured to imperviousness but only when the specimens were small. Mixture 1:2:1 indieates it to be the molecular ratio $1 \mathrm{BeO}: 2 \mathrm{TiO}_{2}: 1 \mathrm{ZrO}_{2}$ and is not intended to infer a compound formulation.

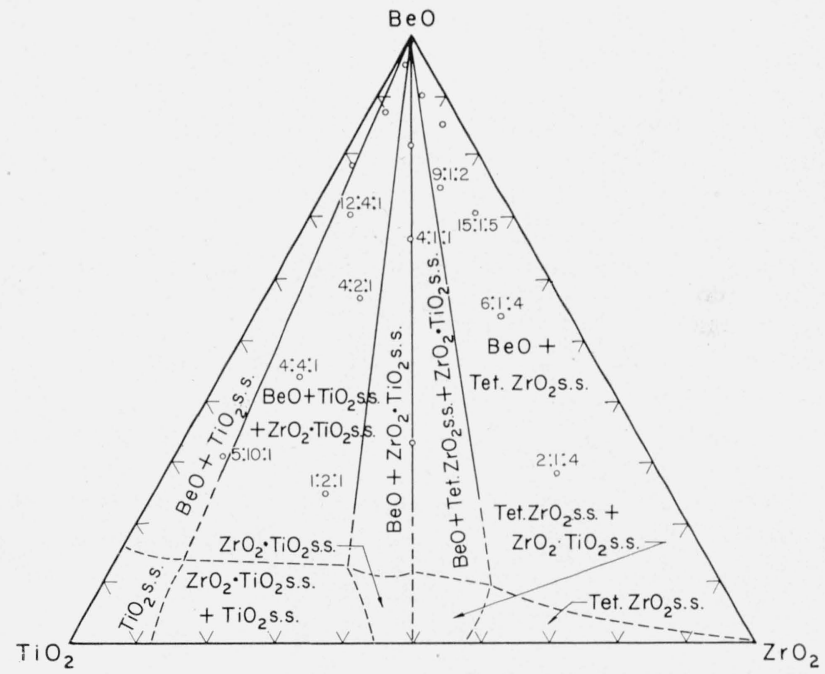

Figure 2. Isothermal section of the system $\mathrm{BeO}-\mathrm{TiO}_{2}-\mathrm{ZrO}_{2}$ at $1,550^{\circ} \mathrm{C}$.

The equilibria shown between zero and 20 mole percent of $\mathrm{BeO}$ are base only upon the reported equilibria for the $\mathrm{TiO}_{2}-\mathrm{ZrO}_{2}$ system. The mole ratio mixtures are located on the diagram on a mole percent basis. Mixture 1:2:1 indicates it to be the molecular ratio $1 \mathrm{BeO}: 2 \mathrm{TiO}_{2}: 1 \mathrm{ZrO}_{2}$ and is not intended to infer a compound formulation.

present in these mixtures, indicating that the $\mathrm{ZrO}_{2} \cdot \mathrm{TiO}_{2}$ compound had not crystallized completely during cooling.

\subsection{Ceramic Bodies}

Table 1 gives the property values determined for specimens fired in an electrically heated furnace and used for preliminary maturing range studies (about $1 / 2$ in. high) and for those fired in a gas-heated furnace 
TABLE 1. Maturing-range studies and compressive-strength results of some $\mathrm{BeO}-\mathrm{TiO}_{2}-\mathrm{ZrO}_{2}$ porcelains

\begin{tabular}{|c|c|c|c|c|c|c|c|c|c|c|c|c|c|c|c|c|}
\hline \multicolumn{6}{|c|}{ Composition } & \multicolumn{5}{|c|}{ Results of maturing-range studies a } & \multicolumn{6}{|c|}{ Properties of compressive-strength specimens ${ }^{b}$} \\
\hline \multicolumn{3}{|c|}{ Molecular } & \multicolumn{3}{|c|}{ Weight } & \multirow[b]{2}{*}{$\begin{array}{l}\text { Maturing e } \\
\text { range }\end{array}$} & \multicolumn{4}{|c|}{ Properties at maturity } & \multirow{2}{*}{$\begin{array}{l}\text { Firing } \\
\text { temper- } \\
\text { ature }\end{array}$} & \multirow{2}{*}{$\begin{array}{c}\text { Shrink- } \\
\text { age } \\
( \pm 0.05)\end{array}$} & \multirow{2}{*}{$\begin{array}{c}\text { Absorp- } \\
\text { tion } \\
( \pm 0.005)\end{array}$} & \multirow{2}{*}{$\begin{array}{c}\text { Bulk d } \\
\text { density } \\
( \pm 0.005)\end{array}$} & \multirow{2}{*}{$\begin{array}{c}\text { Height: } \\
\text { diame- } \\
\text { ter } \\
\text { ratio }\end{array}$} & \multirow{2}{*}{$\begin{array}{l}\text { Strength e } \\
\text { at room } \\
\text { tempera- } \\
\text { ture } \\
( \pm 5,000)\end{array}$} \\
\hline $\mathrm{BeO}$ & $\mathrm{TiO}_{2}$ & $\mathrm{ZrO}_{2}$ & $\begin{array}{c}\mathrm{BeO} \\
( \pm 0.01)\end{array}$ & $\begin{array}{c}\mathrm{TiO}_{2} \\
( \pm 0.01)\end{array}$ & $\begin{array}{c}\mathrm{ZrO}_{2} \\
( \pm 0.01)\end{array}$ & & $\begin{array}{l}\text { Firing } \\
\text { temper- } \\
\text { ature }\end{array}$ & $\begin{array}{c}\text { Shrink- } \\
\text { age } \\
( \pm 0.05)\end{array}$ & $\begin{array}{c}\text { Absorp- } \\
\text { tion } \\
( \pm 0.005)\end{array}$ & $\begin{array}{c}\text { Bulk d } \\
\text { density } \\
( \pm 0.005)\end{array}$ & & & & & & \\
\hline $\begin{array}{l}1 \\
1 \\
2 \\
4 \\
4\end{array}$ & $\begin{array}{l}1 \\
2 \\
1 \\
1 \\
2\end{array}$ & $\begin{array}{l}1 \\
1 \\
4 \\
1 \\
1\end{array}$ & $\begin{array}{c}\% \\
10.97 \\
8.12 \\
8.03 \\
33.01 \\
26.12\end{array}$ & $\begin{array}{c}\% \\
35.02 \\
51.88 \\
12.83 \\
26.35 \\
41.71\end{array}$ & $\begin{array}{c}\% \\
54.01 \\
40.00 \\
79.14 \\
40.64 \\
32.17\end{array}$ & $\begin{array}{c}{ }^{\circ} C . \\
\text { O.F. } 1,550 \\
\text { O.F. } 1,500 \\
\text { O.F. } 1,550 \\
1,500 \text { to } 1,550 \\
1,500 \text { to } 1,550\end{array}$ & $\begin{array}{l}{ }^{\circ} \mathrm{C} . \\
1,550 \\
1,550 \\
1,55\end{array}$ & \begin{tabular}{l}
$\%$ \\
\hdashline.- \\
\hdashline 15.6 \\
16.7
\end{tabular} & $\begin{array}{c}\% \\
0.00 \\
.00\end{array}$ & \begin{tabular}{c}
$\mathrm{g} / \mathrm{cm}^{3}$ \\
\hdashline..- \\
3.82 \\
3.96
\end{tabular} & \begin{tabular}{l}
${ }^{\circ} \mathrm{C}$. \\
\hdashline 1,525 \\
1,525
\end{tabular} & \begin{tabular}{c}
$\%$ \\
\hdashline.-- \\
17.5 \\
18.7
\end{tabular} & $\begin{array}{c}\% \\
0.01 \\
01\end{array}$ & \begin{tabular}{c}
$\mathrm{g} / \mathrm{cm}^{3}$ \\
\hdashline$-\cdot-$ \\
3.87 \\
4.02
\end{tabular} & $\begin{array}{l}-. . \\
-98 \\
1.97 \\
1.97\end{array}$ & $\begin{array}{c}l b / \text { in. }^{2} \\
203 \times 10^{3} \\
244\end{array}$ \\
\hline $\begin{array}{l}4 \\
5 \\
6 \\
9 \\
9\end{array}$ & $\begin{array}{r}4 \\
10 \\
1 \\
1 \\
1\end{array}$ & $\begin{array}{l}1 \\
1 \\
4 \\
1 \\
2\end{array}$ & $\begin{array}{l}18.43 \\
11.94 \\
20.77 \\
52.58 \\
40.83\end{array}$ & $\begin{array}{l}58.87 \\
76.29 \\
11.05 \\
18.65 \\
14.49\end{array}$ & $\begin{array}{l}22.70 \\
11.77 \\
68.18 \\
28.77 \\
44.68\end{array}$ & $\begin{array}{l}1,500 \text { to } 1,550 \\
1,500 \text { to } 1,550 \\
\text { O.F. } 1,550 \\
1,500 \text { to } 1,550 \\
\text { O.F. } 1,650\end{array}$ & $\begin{array}{l}1,550 \\
1,550 \\
1,559 \\
-\cdots\end{array}$ & $\begin{array}{l}16.8 \\
16.8 \\
16.3 \\
-\ldots\end{array}$ & $\begin{array}{r}.00 \\
.00 \\
-.01 \\
. .-\end{array}$ & \begin{tabular}{r}
3.92 \\
3.85 \\
\hdashline 3.43 \\
.--
\end{tabular} & $\begin{array}{l}1,550 \\
1,550 \\
1,525 \\
-\ldots-.-\end{array}$ & $\begin{array}{l}18.3 \\
18.1 \\
17.8 \\
-. .\end{array}$ & \begin{tabular}{r}
.01 \\
.01 \\
\hdashline .00 \\
..-
\end{tabular} & $\begin{array}{r}3.95 \\
3.90 \\
-3.42 \\
-. .-\end{array}$ & $\begin{array}{l}1.95 \\
1.97 \\
2.02 \\
-. .\end{array}$ & $\begin{array}{r}233 \\
239 \\
227\end{array}$ \\
\hline $\begin{array}{l}12 \\
15 \\
30 \\
30 \\
36\end{array}$ & $\begin{array}{l}4 \\
1 \\
1 \\
1 \\
4\end{array}$ & $\begin{array}{l}1 \\
5 \\
2 \\
4 \\
1\end{array}$ & $\begin{array}{l}40.41 \\
35.03 \\
69.70 \\
56.72 \\
67.04\end{array}$ & $\begin{array}{r}43.01 \\
7.46 \\
7.42 \\
6.04 \\
23.79\end{array}$ & $\begin{array}{r}16.58 \\
57.51 \\
22.88 \\
37.24 \\
9.17\end{array}$ & $\begin{array}{c}1,500 \text { to } 1,600 \\
\text { O.F. } 1,550 \\
\text { O.F. 1, } 500 \\
\text { O.F. } 1,550 \\
1,450 \text { to } 1,550\end{array}$ & $\begin{array}{l}1,500 \\
-1,500\end{array}$ & $\begin{array}{l}17.8 \\
-.- \\
18.7\end{array}$ & $\begin{array}{r}.00 \\
\cdots \cdots \\
-.0 \\
-00\end{array}$ & $\begin{array}{c}3.63 \\
-\cdots \\
-.- \\
3.27\end{array}$ & $\begin{array}{l}1,525 \\
-1,525\end{array}$ & $\begin{array}{l}21.4 \\
-.- \\
-\cdot- \\
20.4\end{array}$ & $\begin{array}{r}.01 \\
-. . .- \\
-. .- \\
.01\end{array}$ & $\begin{array}{c}3.63 \\
-\cdots \\
3.27\end{array}$ & \begin{tabular}{l}
2.05 \\
..- \\
\hdashline 1.98
\end{tabular} & $\begin{array}{c}271 \\
-14 \\
241\end{array}$ \\
\hline $\begin{array}{l}40 \\
60\end{array}$ & $\begin{array}{r}10 \\
2\end{array}$ & $\begin{array}{l}1 \\
1\end{array}$ & $\begin{array}{l}52.26 \\
84.14\end{array}$ & $\begin{array}{r}41.30 \\
8.95\end{array}$ & $\begin{array}{l}6.44 \\
6.91\end{array}$ & $\begin{array}{l}1,450 \text { to } 1,600 \\
1,550 \text { to } 1,600\end{array}$ & $\begin{array}{l}1,550 \\
1,550\end{array}$ & $\begin{array}{l}18.3 \\
18.1\end{array}$ & $\begin{array}{l}.00 \\
.00\end{array}$ & $\begin{array}{l}\text { 3. } 41 \\
\text { 3. } 00\end{array}$ & $\begin{array}{l}1,550 \\
1,550\end{array}$ & $\begin{array}{l}20.5 \\
20.0\end{array}$ & $\begin{array}{l}.01 \\
.01\end{array}$ & $\begin{array}{l}\text { 3. } 39 \\
\text { 2. } 96\end{array}$ & $\begin{array}{l}1.99 \\
1.94\end{array}$ & $\begin{array}{l}250 \\
221\end{array}$ \\
\hline
\end{tabular}

a All specimens for this determination were heated in an electrically heated furnace ( $\mathrm{ThO}_{2}$ resistor-type) for $1 \mathrm{hr}$. at the temporatures indicated.

b All specimens for this determination were heated in a gas-fired furnace for $1 \mathrm{hr}$. at the temperatures indicated.

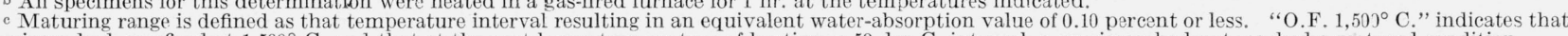

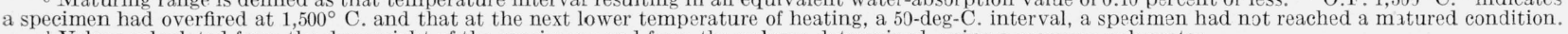

d Values calculated from the dry weight of the specimens and from the volume determined, using a mercury volumeter.

e The numerical average of three test values.

and used for the compressive-strength tests (about $1 \frac{1}{4}$ in. high). Although both were made in the same manner, it should be noted that shrinkage and bulk density values obtained for the larger specimens fired in the gas-heated furnace were higher than those for the smaller specimens fired in the electrically. heated furnace at the same apparent temperatures. The area of the ternary diagram (fig. 1) between the heavy dash-line and the $\mathrm{BeO}-\mathrm{TiO}_{2}$ join indicates the mixtures that could be matured to an impervious condition.

Table 2 gives the maturing data, the flexural strength, and elasticity both at room temperature and at $1,800^{\circ} \mathrm{F}\left(982^{\circ} \mathrm{C}\right)$ determined statically, and
Young's modulus, shear modulus, Poisson's ratio, and bulk modulus determined sonically at room. temperature. It should be noted that the value of Poisson's ratio for $\mathrm{BeO}-\mathrm{TiO}_{2}-\mathrm{ZrO}_{2}$ porcelains ranges between 0.17 and 0.24 .

When the bars for these tests were first made, it was found that those that did not contain at least 70 weight percent of $\mathrm{BeO}$ had cracked during the maturing treatment. Unfortunately, these cracks were all internal, and they were not found until the specimens had been ground to size for the transverse-strength tests. Another set of specimens was made, which behaved identically. When a third set of specimens was made in which 2 weight percent

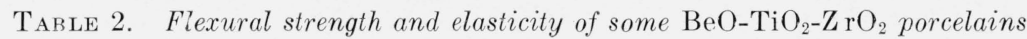

\begin{tabular}{|c|c|c|c|c|c|c|c|c|c|c|c|c|c|c|c|}
\hline \multirow{3}{*}{$\begin{array}{l}\text { Mole a } \\
\text { composi- } \\
\text { tion } \\
\text { BeO:TiO2: } \\
\quad \mathrm{ZrO}^{2}\end{array}$} & \multirow{3}{*}{$\begin{array}{l}\text { Num- } \\
\text { her of } \\
\text { speci- } \\
\text { mens b }\end{array}$} & \multicolumn{4}{|c|}{ Maturing data ${ }^{c}$} & \multirow{2}{*}{\multicolumn{4}{|c|}{$\begin{array}{l}\text { Room temperature e } \\
\text { Sonic elastic properties }\end{array}$}} & \multicolumn{6}{|c|}{ Strength in bending (flexural) at $-f$} \\
\hline & & \multirow[b]{2}{*}{$\begin{array}{l}\text { Firing } \\
\text { tem- } \\
\text { pera- } \\
\text { ture }\end{array}$} & \multirow[b]{2}{*}{$\begin{array}{l}\text { Absorp- } \\
\text { nion }\end{array}$} & \multicolumn{2}{|c|}{ Bulk density d } & & & & & \multicolumn{3}{|c|}{ Room temperature } & \multicolumn{3}{|c|}{$1,800^{\circ} \mathrm{F}\left(982^{\circ} \mathrm{C}\right)$} \\
\hline & & & & $\begin{array}{l}\text { Calcu- } \\
\text { lated }\end{array}$ & $\begin{array}{l}\text { Mer- } \\
\text { cury }\end{array}$ & $\begin{array}{l}\text { Young's } \\
\text { modulus }\end{array}$ & $\begin{array}{l}\text { Shear } \\
\text { modulus }\end{array}$ & $\begin{array}{l}\text { Pois- } \\
\text { son's } \\
\text { ratio }\end{array}$ & $\begin{array}{l}\text { Bulk } \\
\text { modulus }\end{array}$ & $\begin{array}{l}\text { Num- } \\
\text { ber of } \\
\text { speci- } \\
\text { mens }\end{array}$ & $\begin{array}{l}\text { Transverse } \\
\text { strength }\end{array}$ & $\begin{array}{l}\text { Young's } \\
\text { modulus }\end{array}$ & $\begin{array}{l}\text { Num- } \\
\text { ber of } \\
\text { speci- } \\
\text { mens }\end{array}$ & $\begin{array}{l}\text { Transverse } \\
\text { strength }\end{array}$ & $\begin{array}{l}\text { Young's } \\
\text { modulus }\end{array}$ \\
\hline $\begin{array}{l}4: 4: 1 \mathrm{C} \\
5: 10: 1 \mathrm{C} \\
9: 1: 1 \\
12: 4: 1 \\
12: 4: 1\end{array}$ & $\begin{array}{l}3 \\
1 \\
6 \\
4 \\
4\end{array}$ & $\begin{array}{l}{ }^{\circ} C \\
1,550 \\
1,550 \\
1,525 \\
1,525 \\
1,525\end{array}$ & $\begin{array}{r}\% \\
0.99 \\
.80 \\
.01 \\
.02 \\
.01\end{array}$ & $\begin{array}{l}\mathrm{g} / \mathrm{cm}^{3} \\
3.66 \\
3.58 \\
3.55 \\
3.51 \\
3.56\end{array}$ & $\begin{array}{l}\mathrm{g} / \mathrm{cm}^{3} \\
3.68 \\
3.60 \\
3.55 \\
3.52 \\
3.57\end{array}$ & $\begin{array}{l}\text { lb/in. } .^{2} \\
\text { 18. } 7 \times 10^{6} \\
20.4 \\
36.4 \\
37.0 \\
38.8\end{array}$ & $\begin{array}{l}\text { lb/in. } .^{2} \\
8.0 \times 10^{6} \\
8.6 \\
14.8 \\
14.9 \\
15.7\end{array}$ & $\begin{array}{l}0.17 \\
.18 \\
.23 \\
.24 \\
.24\end{array}$ & $\begin{array}{l}\text { lb/in. } .^{2} \\
5.3 \times 10^{6} \\
5.8 \\
9.9 \\
9.9 \\
10.4\end{array}$ & $\begin{array}{c}1 \\
-2 \\
2 \\
1\end{array}$ & $\begin{array}{l}\text { lb/in } .^{2} \\
(6.0) \times 10^{3} \\
12.0 \\
14.3 \\
18.1\end{array}$ & $\begin{array}{c}\text { lb/in.2 }{ }^{2} \\
18.7 \times 10^{6} \\
39.5 \\
38.3 \\
36.9\end{array}$ & $\begin{array}{l}2 \\
1 \\
3 \\
1 \\
2\end{array}$ & $\begin{array}{l}\text { lb/in.2 } \\
11.9 \times 10^{3} \\
9.1 \\
15.0 \\
16.5 \\
15.1\end{array}$ & $\begin{array}{l}\quad l b / \text { in }^{2} \\
21.5 \times 10^{6} \\
23.5 \\
29.0 \\
31.8 \\
26.7\end{array}$ \\
\hline $\begin{array}{l}36: 4: 1 \\
36: 4: 1 \mathrm{C} \\
40: 10: 1 \\
60: 2: 1\end{array}$ & $\begin{array}{l}4 \\
6 \\
2 \\
7\end{array}$ & $\begin{array}{l}1,500 \\
1,500 \\
1,550 \\
1,550\end{array}$ & $\begin{array}{l}.01 \\
.36 \\
.01 \\
.35\end{array}$ & $\begin{array}{l}3.24 \\
3.09 \\
3.36 \\
2.96\end{array}$ & $\begin{array}{l}\text { 3. } 24 \\
\text { 3. } 11 \\
\text { 3. } 36 \\
\text { 2. } 99\end{array}$ & $\begin{array}{l}\text { 43. } 6 \\
40.6 \\
43.0 \\
41.2\end{array}$ & $\begin{array}{l}18.1 \\
16.7 \\
17.7 \\
17.3\end{array}$ & $\begin{array}{l}.20 \\
.22 \\
.22 \\
.19\end{array}$ & $\begin{array}{l}12.1 \\
11.1 \\
11.8 \\
11.5\end{array}$ & $\begin{array}{l}2 \\
2 \\
1 \\
2\end{array}$ & $\begin{array}{l}16.6 \\
15.1 \\
18.9 \\
14.5\end{array}$ & $\begin{array}{l}44.6 \\
38.1 \\
41.9 \\
46.8\end{array}$ & $\begin{array}{l}1 \\
4 \\
1 \\
4\end{array}$ & $\begin{array}{l}16.5 \\
11.5 \\
12.1 \\
10.8\end{array}$ & $\begin{array}{l}38.3 \\
30.8 \\
31.1 \\
29.2\end{array}$ \\
\hline
\end{tabular}

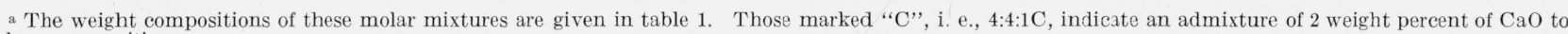
the base composition.

$\mathrm{b}$ Because of cracking, only a limited number of specimons wara obtained.

c All specimens were heated in a gas-fired furnace for $1 \mathrm{hr}$ at the temperatures indicated.

d These values were calculated from the dry weight and the measured dimensions, and from the volumes determined, using a mercury volumeter.

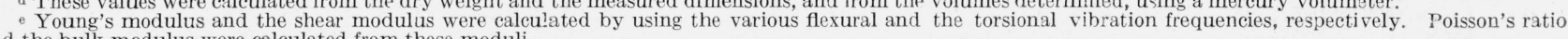
and the bulk modulus were calculated from these moduli.

f These values were determined statically. 
of $\mathrm{CaO}$ was added to the base mixture, a larger percentage of usable specimens was obtained. It was expected that the $\mathrm{CaO}$ admixture would form. a stabilized, cubic zirconia instead of a monoclinic or tetragonal zirconia phase. It was not known at that time that the compound $\mathrm{ZrO}_{2} \cdot \mathrm{TiO}_{2}$ exists. When the compound was identified and its properties determined [19], it was reasoned that the crystallographic transformation of the compound was responsible for the observed cracking of the specimens rather than the phase transformation of zirconia.

Although the crystallographic data are not thoroughly understood at present, it is known that the unit-cell dimension of the $c$-axis of $\mathrm{ZrO}_{2} \cdot \mathrm{TiO}_{2}$ undergoes a large change (from 5.447 to $5.483 \mathrm{~A}$ ) in the interval between $800^{\circ}$ and $1,200^{\circ} \mathrm{C}$. This could easily account for the cracking of the large, barshaped specimens formed in the first and second trials. Although it is a matter of conjecture, because time did not permit investigation, it is believed that $\mathrm{ZrO}_{2} \cdot \mathrm{TiO}_{2}$ formed from $\mathrm{CaO}$-stabilized, cubic zirconia undergoes to only a small extent, if at all, the crystallographic phase transformation associated with material formed from either monoclinic or tetragonal zirconia. ${ }^{4}$

Table 3 gives the results of the short-time $(1 \mathrm{hr})$ stress-strain tests at $1,800^{\circ} \mathrm{F}$ for some $\mathrm{BeO}_{-} \mathrm{TiO}_{2-}$ $\mathrm{ZrO}_{2}$ porcelains, and their strain rates under $6,000-$, $9,000-$, and $12,000-\mathrm{lb} / \mathrm{in}^{2}{ }^{2}$ stress for $5-, 10-, 20-, 30-$, and 60 -min intervals. At $12,000-\mathrm{lb} /$ in. $^{2}$ stress, the strain rates for these were intermediate between those of the $\mathrm{BeO}-\mathrm{Al}_{2} \mathrm{O}_{3}-\mathrm{ZrO}_{2}[3]$ and the $\mathrm{BeO}-\mathrm{Al}_{2} \mathrm{O}_{3}-$ $\mathrm{TiO}_{2}[4]$ porcelains.

\section{The System $\mathrm{BeO}-\mathrm{CeO}_{2}-\mathrm{ZrO}_{2}$}

\subsection{Phase Relations \\ a. The System $\mathrm{BeO}-\mathrm{CeO}_{2}$}

In two papers, von Wartenberg and coworkers $[6,20]$ renorted this system to be a simple one, with

${ }^{4}$ uspuplisned data have been obtained by Coughanour and Roth to eheck this theory. They found that $\mathrm{ZrO}_{2} \cdot \mathrm{TiO}_{2}$, formed from $\mathrm{CaO}$-stabilized, cubic zirconia has a $c$-axis of $5.459 \mathrm{~A}$ when quenched from $1,550^{\circ} \mathrm{C}$ and $5.440 \mathrm{~A}$ when furnace-cooled from $1,475^{\circ} \mathrm{C}$. This difference represents approximately one-half of the $c$-axis change observed, using pure $\mathrm{ZrO}_{2} \cdot \mathrm{TiO}_{2}$, and, in general, agrees with both the proposed theory and the results of this investigation. the eutectic at about 80 weight percent of $\mathrm{CeO}_{2}$ and $1,960^{\circ} \mathrm{C}$. The volatilization of $\mathrm{CeO}_{2}$ was said to be very slight, but that of $\mathrm{Ce}_{2} \mathrm{O}_{3}$, which forms easily and melts at about $1,690^{\circ} \mathrm{C}$, as appreciable over $2,000^{\circ} \mathrm{C}$.

\section{b. The System BeO- $\mathrm{ZrO}_{2}$}

The equilibria are described in section 3.1 , b.

\section{c. The System $\mathrm{CeO}_{2}-\mathrm{ZrO}_{2}$}

This system has been given as a simple one with a minimum at about 40 weight percent of $\mathrm{ZrO}_{2}$ and $2,400^{\circ} \mathrm{C}$ [10] and, also at about $2,300^{\circ} \mathrm{C}$. [20]. Considerable solid solution in the system, involving change of the zirconia lattice to a cubic fluorite-type lattice, has been reported [8, 21]. Recently, it was shown that a tetragonal, not cubic, zirconia solidsolution phase is formed $[22,23,24]$. Duwez and Odell [24] proposed a diagram to satisfy the following equilibria relations: (1) A tetragonal zirconia solid solution containing approximately 10 mole percent of $\mathrm{CeO}_{2}$, and transformation to a monoclinic solid-solution form below $1,000^{\circ} \mathrm{C},(2)$ extensive cubic solid solution from about 24 to 100 mole percent of $\mathrm{CeO}_{2}$ at $2,000^{\circ} \mathrm{C}$, (3) a narrow two-phase region at $2,000^{\circ}$ near 20 mole percent of $\mathrm{CeO}_{2}$, and (4) extension of the two-phase region with lowering of temperature, so that the cubic $\mathrm{CeO}_{2}$ solid-solution range extends from about 65 mole percent at $1,375^{\circ}$ to about 90 mole percent of $\mathrm{CeO}_{2}$ at $1,100^{\circ} \mathrm{C}$.

\section{d. The System $\mathrm{BeO}-\mathrm{CeO}_{2}-\mathrm{ZrO}_{2}$}

At temperatures above $1,970^{\circ} \mathrm{C}$, Ruff and coworkers [25] made isothermal studies of the melting of ternary mixtures containing at least 50 mole percent of $\mathrm{ZrO}_{2}$. Curtis [23] investigated specimens of a few ternary mixtures containing at least 80 mole percent of $\mathrm{ZrO}_{2}$ and found that a body composed of about 10 mole percent of $\mathrm{BeO}, 10$ mole percent of $\mathrm{CeO}_{2}$, and 80 mole percent of $\mathrm{ZrO}_{2}$ appeared to have the best thermal-shock resistance.

Figure 3 shows an isothermal section of this system based upon X-ray examination of specimens that had been heated at $1,750^{\circ} \mathrm{C}$ during the maturing-

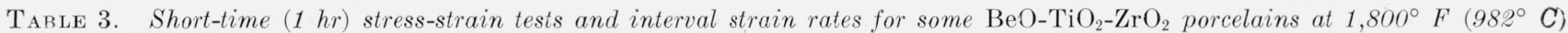
All rates of strain are $n \times 10^{-6}$ (in./in.)/min.

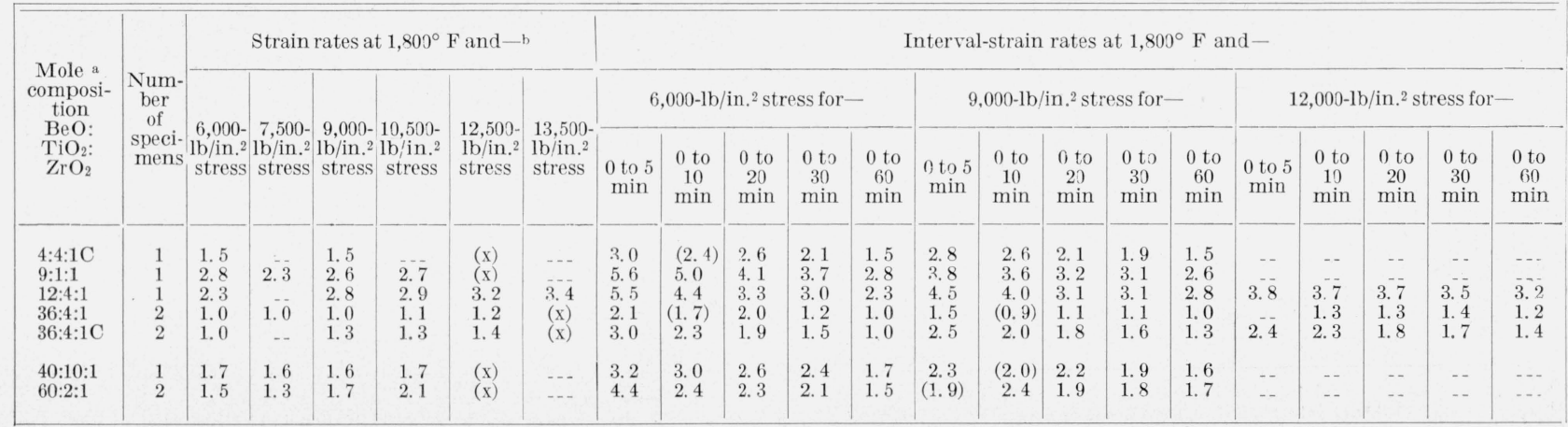

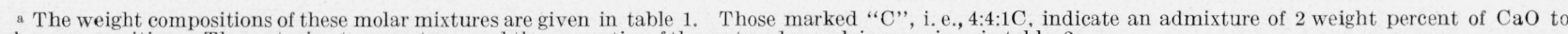
the base composition. The maturing temperatures and the properties of the matured porcelains are given in table 2 .

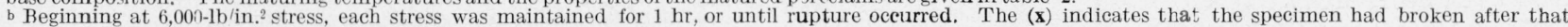
stress was applied but hefore the hourly period had elapsed. 


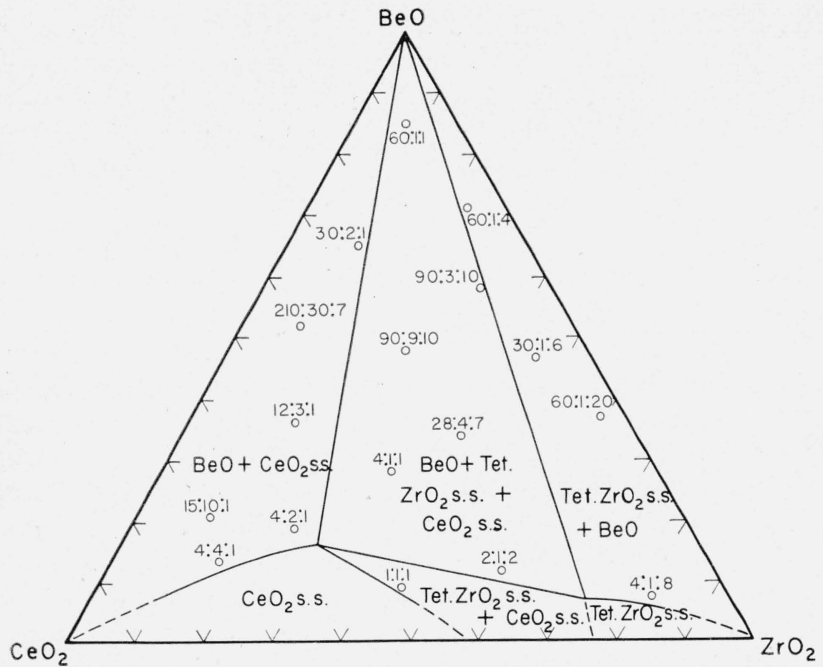

Figure 3. Isothermal section of the system $\mathrm{BeO}-\mathrm{CeO}_{2}-\mathrm{ZrO}_{2}$ at $1,750^{\circ} \mathrm{C}$.

The compositions of the mixtures are indicated on the figure in molar ratios, but are placed graphically according to weight percentages. Mixture 4:1:8 indicates it to be the molecular ratio $4 \mathrm{BeO}: 1 \mathrm{CeO}_{2}: 8 \mathrm{ZrO}_{2}$ and is not intended to infer a compound formulation.

range tests. Each sample was sectioned so that an interior surface could be used to prepare the X-ray diffraction patterns. The data indicate that this is a system of partial solid solutions with no binary or ternary compounds. Although $\mathrm{BeO}$ has not been reported as forming solid solutions with either $\mathrm{CeO}_{2}$ or $\mathrm{ZrO}_{2}$, it is apparent that it did enter both of the $\mathrm{CeO}-\mathrm{ZrO}_{2}$ solid solutions. For example, after being heated at $1,750^{\circ} \mathrm{C}$, mixture $1 \mathrm{~B}: 1 \mathrm{Ce}: 1 \mathrm{Z}$ contains no free $\mathrm{BeO}$ but only tetragonal $\mathrm{ZrO}_{2}$ and cubic $\mathrm{CeO}_{2}$ solid solutions. Similarly, mixture $4 \mathrm{~B}: 4 \mathrm{Ce}: 1 \mathrm{Z}$ is almost a single-phase cubic $\mathrm{CeO}_{2}$ solid solution containing only a very small amount of free $\mathrm{BeO}$. It seems likely, therefore, that $\mathrm{BeO}$ should form a solid solution with $\mathrm{CeO}_{2}$ in the binary as well as it does in the ternary system.

For the specimens used in this study, the phases identified at room temperature were the same as those shown at the $1,750^{\circ} \mathrm{C}$ isothermal section, with the following exceptions: Mixtures $4 \mathrm{~B}: 1 \mathrm{Ce}: 8 \mathrm{Z}$, 30B:1Ce:6Z, 60B:1Ce:4Z, and 60B:1Ce:20Z. At room temperature, mixture $60 \mathrm{~B}: 1 \mathrm{Ce}: 20 \mathrm{Z}$ is composed of monoclinic $\mathrm{ZrO}_{2}$ solid solution and $\mathrm{BeO}$. The effect of a larger $\mathrm{CeO}_{2}$ content (as in the other three mixtures) is that $\mathrm{BeO}$ and both monoclinic and tetragonal $\mathrm{ZrO}_{2}$ solid solutions are present. With these data and that from other investigations [12, 23, 24], showing the $1,000^{\circ} \mathrm{C}$ transformation of tetragonal to monoclinic $\mathrm{ZrO}_{2}$ solid solution, it is likely that at $1,750^{\circ} \mathrm{C}$ the four mixtures contain only tetragonal $\mathrm{ZrO}_{2}$ solid solution and $\mathrm{BeO}$.

When ternary mixtures were heated successively at $1,750^{\circ}, 1,800^{\circ}$, and at $1,845^{\circ} \mathrm{C}$ for periods of $30 \mathrm{~min}$ at each temperature, the only liquid formation that could be determined by visual examination at room temperature had occurred in mixture 90B:9Ce:10Z, which had been heated at $1,845^{\circ} \mathrm{C}$. From the data determined for the solid-state reactions at $1,750^{\circ} \mathrm{C}$, it is evident that this is a simple ternary sys em. If the ternary eutectic were to be located at the 90B:9Ce:10Z composition, it would violate the laws of the phase rule, assuming that the phase diagrams of the binary systems, as previously published, are correct. However, it has been shown in this investigation that a solid solution probably exists at the $\mathrm{CeO}_{2}$ side of the $\mathrm{BeO}-\mathrm{CeO}_{2}$ system. If this is true, it seems reasonable to assume that the reported

TABLE 4. Maturing-range studies and compressive-strength results of some $\mathrm{BeO}-\mathrm{CeO}_{2}-\mathrm{ZrO}_{2}$ porcelains

\begin{tabular}{|c|c|c|c|c|c|c|c|c|c|c|c|c|c|c|c|c|c|}
\hline \multicolumn{6}{|c|}{ Composition } & \multicolumn{5}{|c|}{ Results of maturing-range studies ${ }^{a}$} & \multicolumn{7}{|c|}{ Properties of compressive-strength specimens b } \\
\hline \multicolumn{3}{|c|}{ Molecular } & \multicolumn{3}{|c|}{ Weight } & \multirow{2}{*}{$\begin{array}{l}\text { Mat!uring c } \\
\text { range }\end{array}$} & \multicolumn{4}{|c|}{ Properties at maturity } & \multirow{2}{*}{$\begin{array}{c}\text { Firing } \\
\text { temper- } \\
\text { atures }\end{array}$} & \multirow{2}{*}{$\begin{array}{l}\text { Shrink- } \\
\text { age } \\
( \pm 0.05)\end{array}$} & \multirow{2}{*}{$\begin{array}{c}\text { Absorp- } \\
\text { tion } \\
( \pm 0.005)\end{array}$} & \multirow{2}{*}{$\begin{array}{c}\text { Bulk d } \\
\text { density } \\
( \pm 0.005)\end{array}$} & \multirow{2}{*}{$\begin{array}{c}\text { Height: } \\
\text { diam- } \\
\text { eter } \\
\text { ratio }\end{array}$} & \multirow{2}{*}{$\begin{array}{l}\text { Strength } \\
\text { at room } \\
\text { temper- } \\
\text { ature } \\
( \pm 5,000)\end{array}$} & \multirow{2}{*}{$\begin{array}{l}\text { Num- } \\
\text { ber } \\
\text { of } \\
\text { speci- } \\
\text { mens }\end{array}$} \\
\hline $\mathrm{BeO}$ & $\mathrm{CeO}_{2}$ & $\mathrm{ZrO}_{2}$ & $\begin{array}{c}\mathrm{BeO} \\
( \pm 0.01)\end{array}$ & $\begin{array}{c}\mathrm{CeO}_{2} \\
( \pm 0.01)\end{array}$ & $\begin{array}{c}\mathrm{ZrO}_{2} \\
( \pm 0.01)\end{array}$ & & $\begin{array}{l}\text { Firing } \\
\text { temper- } \\
\text { ature }\end{array}$ & $\begin{array}{c}\text { Shrink- } \\
\text { age } \\
( \pm 0.05)\end{array}$ & $\begin{array}{c}\text { A bsorp- } \\
\text { tion } \\
( \pm 0.005)\end{array}$ & $\begin{array}{c}\text { Bulk d } \\
\text { density } \\
( \pm 0.005)\end{array}$ & & & & & & & \\
\hline $\begin{array}{l}1 \\
2 \\
4 \\
4 \\
4 \\
4\end{array}$ & $\begin{array}{l}1 \\
1 \\
1 \\
1 \\
2\end{array}$ & $\begin{array}{l}1 \\
2 \\
1 \\
8 \\
1\end{array}$ & $\begin{array}{r}\% \\
7.81 \\
10.68 \\
25.31 \\
7.96 \\
17.63\end{array}$ & $\begin{array}{c}\% \\
53.73 \\
36.73 \\
43.53 \\
13.68 \\
60.66\end{array}$ & $\begin{array}{c}\% \\
38.46 \\
52.59 \\
31.16 \\
78.36 \\
21.71\end{array}$ & $\begin{array}{l}{ }^{\circ} C \\
\text { O.F. } 1,750 \\
\text { O.F. } 1,700 \\
1,600 \text { to } 1,750 \\
1,600 \text { to } 1,750 \\
1,600 \text { to } 1,700\end{array}$ & \begin{tabular}{c}
${ }^{\circ} C$ \\
\hdashline 1,750 \\
1,700 \\
1,650
\end{tabular} & $\begin{array}{c}\% \\
15.6 \\
13.9 \\
14.7\end{array}$ & $\begin{array}{c}\% \\
0.00 \\
.01 \\
01\end{array}$ & $\begin{array}{c}\mathrm{g} / \mathrm{cm}^{3} \\
4.90 \\
5.14 \\
5.37\end{array}$ & $\begin{array}{l}{ }^{\circ} C \\
1,750 \\
1,750 \\
1,750\end{array}$ & $\begin{array}{c}\% \\
14.9 \\
12.0 \\
16.6\end{array}$ & $\begin{array}{l}\% \\
0.36 \\
2.6 \\
0.06\end{array}$ & $\begin{array}{c}\mathrm{g} / \mathrm{cm}^{3} \\
5.33 \\
4.71 \\
4.63\end{array}$ & $\begin{array}{l}1.84 \\
1.80 \\
1.89\end{array}$ & $\begin{array}{l}l b / \text { in }^{2} \\
147 \times 10^{3} \\
112 \\
184\end{array}$ & $\begin{array}{l}3 \\
2 \\
3\end{array}$ \\
\hline 4 & 2 & 1 & 17. 63 & 60.66 & 21.71 & 1,600 to 1,700 & 1,650 & 14.7 & .01 & 5.37 & 1,700 & 17.1 & .06 & 5.25 & 1.89 & 211 & 1 \\
\hline $\begin{array}{r}4 \\
12\end{array}$ & $\begin{array}{l}4 \\
3\end{array}$ & $\begin{array}{l}1 \\
1\end{array}$ & $\begin{array}{l}10.98 \\
31.95\end{array}$ & $\begin{array}{l}75.51 \\
54.94\end{array}$ & $\begin{array}{l}13.51 \\
13.11\end{array}$ & $\begin{array}{l}1,600 \text { to } 1,750 \\
1,550 \text { to } 1,750\end{array}$ & $\begin{array}{l}1,750 \\
1,700\end{array}$ & $\begin{array}{l}14.4 \\
15.9\end{array}$ & .01 & $\begin{array}{l}5.80 \\
4.71\end{array}$ & 1,750 & 18.4 & .04 & 5.87 & 1.83 & 166 & 4 \\
\hline 15 & $\begin{array}{r}0 \\
10\end{array}$ & 1 & $\begin{array}{l}31.95 \\
16.91\end{array}$ & $\begin{array}{l}54.94 \\
77.54\end{array}$ & $\begin{array}{r}13.11 \\
5.55\end{array}$ & $\begin{array}{l}1,550 \text { to } 1,750 \\
1,650 \text { to } 1,750\end{array}$ & $\begin{array}{l}1,700 \\
1,750\end{array}$ & $\begin{array}{l}15.9 \\
14.4\end{array}$ & .00 & $\begin{array}{l}4.71 \\
5.48\end{array}$ & - & $-\cdots$ & - & - & - & 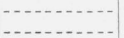 & 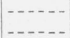 \\
\hline 28 & 4 & 7 & 31.11 & 30.58 & 38.31 & 1,550 to 1,750 & 1,700 & 15.6 & .01 & 4. 53 & & & & & & & \\
\hline 30 & 1 & 6 & 45. 16 & 10.36 & 44.48 & 1,550 to 1,700 & 1,650 & 17. 2 & .00 & 3.99 & 1,650 & 17.7 & .07 & 3.92 & 2.03 & 247 & 1 \\
\hline 30 & 2 & 1 & 61.62 & 28.26 & 10. 12 & 1,550 to 1,700 & 1,700 & 18.0 & .00 & 3.67 & & & & & & & \\
\hline 60 & 1 & 1 & 83.56 & 9.58 & 6.86 & 1,550 to 1,700 & 1,700 & 18.1 & .00 & 3.14 & 1,650 & 17.9 & 1.8 & 2.89 & 1.88 & 199 & 1 \\
\hline 60 & 1 & 4 & 69.30 & 7.95 & 22.75 & 1,550 to 1,700 & 1,700 & 18.0 & .01 & 3.42 & 1.650 & 18.4 & 0.23 & 3.24 & 1.86 & 247 & 1 \\
\hline 60 & 1 & 20 & 36.28 & 4. 16 & 59.56 & O.F. 1,700 & & & & & & $\ldots$ & - & - & - . & $\ldots$. & $\ldots$ \\
\hline 90 & 3 & 10 & 56.29 & 12.91 & 30.80 & 1,550 to 1,750 & 1,750 & 17.6 & .01 & 3.74 & - & . & & - & ........ & - & ....... \\
\hline $\begin{array}{r}90 \\
210\end{array}$ & $\begin{array}{r}9 \\
30\end{array}$ & 10 & $\begin{array}{l}44.74 \\
46.58\end{array}$ & $\begin{array}{l}30.78 \\
45.78\end{array}$ & 24. 48 & 1,550 to 1,750 & 1,750 & 16. 8 & .00 & 4. 13 & 1,700 & 17.1 & .09 & 3.85 & 1.87 & 233 & 1 \\
\hline 210 & 30 & 7 & 46.58 & 45.78 & 7.64 & 1,550 to 1,700 & 1,700 & 16.7 & .00 & 4. 15 & 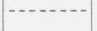 & 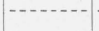 & & & - & & \\
\hline
\end{tabular}

a All specimens for this determination were heated in an electrically heated furnace ( $\mathrm{ThO}_{2}$ resistor-type) for $1 \mathrm{hr}$ at the temperatures indicated.

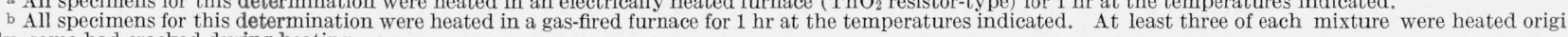
nally, some had cracked during heating.

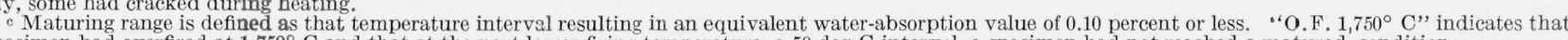
a specimen had overfired at $1,750^{\circ} \mathrm{C}$ and that at the next lower firing temperature, a $50 \cdot d e g \cdot \mathrm{C}$ interval, a specimen had not reached a matured condition.

$\mathrm{d}$ Values calculated from the dry weight of the specimens and from the volume determined, using a mercury volumeter. 
$\mathrm{BeO}-\mathrm{CeO}_{2}$ eutectic composition is incorrect. If it is located between 0 and 40 weight percent of $\mathrm{CeO}_{2}$, the equilibrium diagram of the $\mathrm{BeO}-\mathrm{CeO}_{2}-\mathrm{ZrO}_{2}$ system can be given with the ternary eutectic at about the composition of mole mixture 90B:9Ce:10Z. It is for these reasons that no equilibrium diagram is given for the $\mathrm{BeO}-\mathrm{CeO}_{2}-\mathrm{ZrO}_{2}$ system.

\subsection{Ceramic Bodies}

Table 4 gives the property values determined for specimens fired in an electrically heated furnace and used for the preliminary maturing-range studies, and those of the compressive-strength specimens, fired in a gas-heated furnace. Except for mixtures $1 \mathrm{~B}: 1 \mathrm{Ce}: 1 \mathrm{Z}$ and $2 \mathrm{~B}: 1 \mathrm{Ce}: 2 \mathrm{Z}$, in the area of the heavydash line near the $\mathrm{CeO}_{2}-\mathrm{ZrO}_{2}$ eutectic, and $60 \mathrm{~B}$ : $1 \mathrm{Ce}: 20 \mathrm{Z}$ near the $\mathrm{BeO}-\mathrm{ZrO}_{2}$ eutectic, all of the mixtures shown on figure 3 could be matured to an impervious condition.

Table 5 gives the maturing data, the flexural strength and elasticity, determined statically, both at room temperature and at $1,800^{\circ} \mathrm{F}$, and Young's modulus, shear modulus, Poisson's ratio, and bulk modulus determined sonically at room temperature. The value for Poisson's ratio ranges from 0.21 to 0.28 for these $\mathrm{BeO}-\mathrm{CeO}_{2}-\mathrm{ZrO}_{2}$ porcelains.

In this, as well as in the similar system containing $\mathrm{TiO}_{2}$, considerable difficulty was encountered in forming satisfactorily sound bars for the transversestrength and elasticity tests. Here again, it was found that the cracks that had developed were all internal and were not found until the specimens had been ground to size for the various tests. Only those few bars from the first lot to be formed, which were found to be satisfactory, were used. No attempts were made to form more of the mixtures to usable specimens. It is apparent from figure 3 that the majority of the mixtures used in this study lie within the fields containing tetragonal zirconia at $1,750^{\circ} \mathrm{C}$. In some of the mixtures, this reverts to the monoclinic form during cooling. Both the

TABLE 5. Flexural strength and elasticity of some $\mathrm{BeO}-\mathrm{CeO}_{2}-\mathrm{ZrO}_{2}$ porcelains

\begin{tabular}{|c|c|c|c|c|c|c|c|c|c|c|c|c|c|c|c|}
\hline \multirow{3}{*}{$\begin{array}{c}\text { Mole a } \\
\text { compo- } \\
\text { sition } \\
\mathrm{BeO} \\
\mathrm{CeO}_{2} \text { : } \\
\mathrm{ZrO}_{2}\end{array}$} & \multirow{3}{*}{$\begin{array}{l}\text { Num- } \\
\text { ber } \\
\text { of } \\
\text { speci- } \\
\text { mens }\end{array}$} & \multicolumn{4}{|c|}{ Maturing data ${ }^{c}$} & \multirow{2}{*}{\multicolumn{4}{|c|}{ Room temperature e }} & \multicolumn{6}{|c|}{ Strength in bending (flexural) at $-\mathrm{f}$} \\
\hline & & \multirow{2}{*}{$\begin{array}{l}\text { Fir- } \\
\text { ing } \\
\text { tem- } \\
\text { pera- } \\
\text { ture }\end{array}$} & \multirow[b]{2}{*}{$\begin{array}{l}\text { Absorp- } \\
\text { tion }\end{array}$} & \multicolumn{2}{|c|}{ Bulk density d } & & & & & \multicolumn{3}{|c|}{ Room temperature } & \multicolumn{3}{|c|}{$1,800^{0} \mathrm{~F}\left(982^{\circ} \mathrm{C}\right)$} \\
\hline & & & & $\begin{array}{l}\text { Calcu- } \\
\text { lated }\end{array}$ & $\begin{array}{l}\text { Mer- } \\
\text { cury }\end{array}$ & $\begin{array}{l}\text { Young's } \\
\text { modulus }\end{array}$ & $\begin{array}{l}\text { Shear } \\
\text { modulus }\end{array}$ & $\begin{array}{l}\text { Pois- } \\
\text { son's } \\
\text { ratio }\end{array}$ & $\begin{array}{l}\text { Bulk } \\
\text { modulus }\end{array}$ & $\begin{array}{l}\text { Num- } \\
\text { ber } \\
\text { of } \\
\text { spec- } \\
\text { imens }\end{array}$ & $\begin{array}{l}\text { Trans- } \\
\text { verse } \\
\text { strength }\end{array}$ & $\begin{array}{l}\text { Young's } \\
\text { modulus }\end{array}$ & $\begin{array}{l}\text { Num- } \\
\text { ber } \\
\text { of } \\
\text { spec- } \\
\text { imens }\end{array}$ & $\begin{array}{l}\text { Trans- } \\
\text { verse } \\
\text { strength }\end{array}$ & $\begin{array}{l}\text { Young's } \\
\text { modulus }\end{array}$ \\
\hline $1: 1: 1$ & 4 & ${ }^{0}{ }^{\circ} \mathrm{C}$ & $\begin{array}{c}\% \\
(1.8 \text { to } \\
0.00)\end{array}$ & $\begin{array}{c}\mathrm{g} / \mathrm{cm}^{3} \\
(5.29 \text { to } \\
5.61)\end{array}$ & $\begin{array}{c}\mathrm{g} / \mathrm{cm}^{3} \\
(5.33 \text { to } \\
5.64)\end{array}$ & $\begin{array}{c}\text { lb/in. } .^{2} \\
(22.2 \text { to } \\
\left.26.7 \times 10^{6}\right)\end{array}$ & $\begin{array}{c}\text { lb/in. } .^{2} \\
(8.7 \text { to } \\
\left.10.4 \times 10^{6}\right)\end{array}$ & 0.27 & $\begin{array}{c}l b^{\prime} \text { in } .^{2} \\
\text { (5. } 8 \text { to } \\
\left.6.9 \times 10^{6}\right)\end{array}$ & 2 & $\begin{array}{c}l b / i n .^{2} \\
14.2 \times 10^{3}\end{array}$ & $\begin{array}{c}l b / i n .^{2} \\
22.4 \times 10^{6}\end{array}$ & 2 & $\begin{array}{c}l b / i n .^{2} \\
14.2 \times 10^{3}\end{array}$ & $20.1 \times 10^{6}$ \\
\hline $\begin{array}{l}2: 1: 2 \\
4: 1: 1 \\
4: 2: 1 \\
4: 4: 1\end{array}$ & $\begin{array}{l}4 \\
4 \\
3 \\
4\end{array}$ & $\begin{array}{l}1,750 \\
1.750 \\
1,700 \\
1,750\end{array}$ & $\begin{array}{l}1.2 \\
0.04 \\
.01 \\
.08\end{array}$ & $\begin{array}{l}\text { 5. } 08 \\
\text { 4. } 66 \\
5.35 \\
5.82\end{array}$ & $\begin{array}{l}\text { 5. } 06 \\
\text { 4. } 67 \\
5.40 \\
5.86\end{array}$ & $\begin{array}{l}22.9 \\
30.4 \\
33.0 \\
31.3\end{array}$ & $\begin{array}{r}8.8 \\
12.0 \\
13.0 \\
12.2\end{array}$ & $\begin{array}{l}.28 \\
.26 \\
.27 \\
.28\end{array}$ & $\begin{array}{l}\text { 5. } 9 \\
8.0 \\
8.6 \\
8.2\end{array}$ & $\begin{array}{l}2 \\
2 \\
1 \\
2\end{array}$ & $\begin{array}{l}13.6 \\
17.3 \\
18.8 \\
15.6\end{array}$ & $\begin{array}{l}23.3 \\
30.3 \\
34.7 \\
30.8\end{array}$ & $\begin{array}{l}2 \\
2 \\
2 \\
2\end{array}$ & $\begin{array}{l}15.8 \\
18.1 \\
16.1 \\
13.0\end{array}$ & $\begin{array}{l}17.9 \\
23.2 \\
25.1 \\
20.4\end{array}$ \\
\hline $\begin{array}{l}12: 3: 1 \\
15: 10: 1 \\
30: 2: 1 \\
60: 1: 1 \\
60: 1: 4\end{array}$ & $\begin{array}{l}1 \\
2 \\
2 \\
1 \\
4\end{array}$ & $\begin{array}{l}1,700 \\
1,750 \\
1,700 \\
1,650 \\
1,650\end{array}$ & $\begin{array}{l}.01 \\
.01 \\
3.1 \\
4.4 \\
0.77\end{array}$ & $\begin{array}{l}4.70 \\
5.51 \\
3.35 \\
2.83 \\
3.21\end{array}$ & $\begin{array}{l}\text { 4. } 72 \\
5.58 \\
3.36 \\
2.82 \\
\text { 3. } 22\end{array}$ & $\begin{array}{l}38.2 \\
35.1 \\
30.1 \\
34.0 \\
37.1\end{array}$ & $\begin{array}{l}15.2 \\
13.8 \\
12.3 \\
14.1 \\
15.1\end{array}$ & $\begin{array}{l}.25 \\
.27 \\
.22 \\
.21 \\
.23\end{array}$ & $\begin{array}{r}10.2 \\
9.2 \\
8.2 \\
9.4 \\
10.1\end{array}$ & $\begin{array}{l}1 \\
1 \\
2\end{array}$ & $\begin{array}{l}19.7 \\
12.0 \\
23.4\end{array}$ & $\begin{array}{l}35.8 \\
29.5 \\
38.4\end{array}$ & $\begin{array}{l}1 \\
1 \\
1 \\
1 \\
2\end{array}$ & $\begin{array}{l}18.0 \\
19.5 \\
12.1 \\
12.0 \\
16.6\end{array}$ & $\begin{array}{l}24.8 \\
26.2 \\
23.9 \\
25.3 \\
28.9\end{array}$ \\
\hline $90: 9: 10$ & 1 & 1,700 & 1.8 & 3. 79 & 3.79 & 30.7 & 12.3 & .25 & 8.2 & - & & & 1 & 16.6 & 26.7 \\
\hline
\end{tabular}

a The weight compositions of these molar mixtures are given in table 4.

b Because of firing cracking, only a limited number of specimens were obtained.

- All of the specimens were heated in a gas-fired furnace for $1 \mathrm{hr}$ at the temperatures indicated.

d These values were calculated from the dry weights and the measured dimensions, and from the volumes determined, using a mercury volumeter.

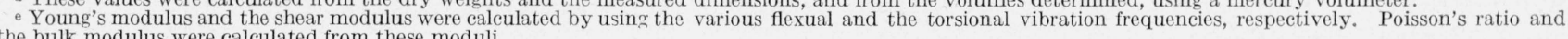
the bulk modulus were calculated from these moduli.

f These values were determined statically.

TABLE 6. Short-time $(1 \mathrm{hr})$ stress-strain tests and interval strain rates for some $\mathrm{BeO}_{-} \mathrm{CeO}_{2}-\mathrm{ZrO}_{2}$ porcelains All rates of strain are $n \times 10^{-6}$ (in./in.) $/ \mathrm{min}$.

\begin{tabular}{|c|c|c|c|c|c|c|c|c|c|c|c|c|c|c|c|c|c|c|c|c|c|}
\hline \multirow{3}{*}{$\begin{array}{c}\text { Mole a } \\
\text { composition } \\
{\mathrm{BeO}: \mathrm{CeO}_{2}:-}^{\mathrm{TiO}_{2}}\end{array}$} & \multicolumn{6}{|c|}{ Strain rates at $1,800^{\circ} \mathrm{F} .\left(982^{\circ} \mathrm{C}\right.$.) and-b } & \multicolumn{15}{|c|}{ Interval strain rates at $1,800^{\circ} \mathrm{F}$. and- } \\
\hline & \multirow{2}{*}{$\begin{array}{l}\text { 6, } 000- \\
\text { lb/in. } \\
\text { stress }\end{array}$} & \multirow[b]{2}{*}{$\begin{array}{l}9,000- \\
1 \mathrm{~b} / \mathrm{in}^{2} \\
\text { stress }\end{array}$} & \multirow[b]{2}{*}{$\begin{array}{l}12,000- \\
\text { lb/in. } \\
\text { stress }\end{array}$} & \multirow[b]{2}{*}{$\begin{array}{l}13,500- \\
\text { lb/in. } \\
\text { stress }\end{array}$} & \multirow[b]{2}{*}{$\begin{array}{l}15,000- \\
\text { lb/in. }{ }^{2} \\
\text { stress }\end{array}$} & \multirow[b]{2}{*}{$\begin{array}{l}16,500- \\
\text { lb/in. } \\
\text { stress }\end{array}$} & \multicolumn{5}{|c|}{$6,000-\mathrm{lb} / \mathrm{in} .^{2}$ stress for- } & \multicolumn{5}{|c|}{12,000 -lb/in..$^{2}$ stress for- } & \multicolumn{5}{|c|}{15,000 -lb/in..$^{2}$ stress for- } \\
\hline & & & & & & & $\begin{array}{c}0 \text { to } \\
5 \mathrm{~min}\end{array}$ & $\begin{array}{l}0 \text { to } \\
10 \\
\text { min }\end{array}$ & $\begin{array}{l}0 \text { to } \\
20 \\
\text { min }\end{array}$ & $\begin{array}{l}0 \text { to } \\
30 \\
\min \end{array}$ & $\begin{array}{l}0 \text { to } \\
60 \\
\min \end{array}$ & $\begin{array}{c}0 \text { to } \\
5 \mathrm{~min}\end{array}$ & $\begin{array}{l}0 \text { to } \\
10 \\
\text { min }\end{array}$ & $\begin{array}{l}0 \text { to } \\
20 \\
\text { min }\end{array}$ & $\begin{array}{l}0 \text { to } \\
30 \\
\text { min }\end{array}$ & $\begin{array}{l}0 \text { to } \\
60 \\
\text { min }\end{array}$ & $\begin{array}{c}0 \text { to } \\
5 \mathrm{~min}\end{array}$ & $\begin{array}{l}0 \text { to } \\
10 \\
\text { min }\end{array}$ & $\begin{array}{l}0 \text { to } \\
20 \\
\text { min }\end{array}$ & $\begin{array}{l}0 \text { to } \\
30 \\
\text { min }\end{array}$ & $\begin{array}{c}0 \text { to } \\
60 \\
\text { min }\end{array}$ \\
\hline $1: 1: 1$ & 0.9 & 0.6 & 0.7 & $(\mathrm{x})$ & & & 2.9 & 2.3 & 1.5 & 1.3 & 0.9 & 2.3 & 1. 6 & 0.9 & 0.7 & 0.7 & & & & & \\
\hline $\begin{array}{l}1.1 .1 \\
2: 1: 2\end{array}$ & 1.0 & .6 & .9 & 0.9 & 1.1 & $(\mathrm{x})$ & 3.3 & 2.8 & 1. & $\begin{array}{l}1.0 \\
1.3\end{array}$ & 1.0 & 1.6 & 1. 1 & .9 & .9 & 9 & $1 . \overline{9}$ & $1 . \overline{6}$ & $1 . \overline{3}$ & $1 . \overline{3}$ & $1 . \overline{1}$ \\
\hline $4: 1: 1$ & 0.8 & 1. 0 & 1. 0 & 0.0 & 1. 3 & 1.1 & $(1.4)$ & 1.8 & 1. 2 & 1. 1 & 0.8 & $(1.9)$ & 1. 9 & 1.4 & 1. 2 & 1. 0 & 2. 6 & 2. 3 & 1. 9 & 1.6 & 1.3 \\
\hline $4: 2: 1$ & .8 & 1. 0 & 0.8 & .8 & 0.7 & 0.9 & 3.4 & 2. 2 & 1.5 & 1. 3 & .8 & 1.7 & 1. 1 & 1. 2 & 1. 0 & 0.8 & 1. 0 & 0.8 & 0.9 & 0.8 & 0.7 \\
\hline $4: 4: 1$ & 1. 2 & 0.4 & 1. 2 & (x) & - - &.- & 3.1 & 2.8 & 2.0 & 1. 8 & 1. 2 & $(1.8)$ & 1. 9 & 1.8 & 1. 7 & 1. 2 & - & -. &.- & -- & -. \\
\hline $60: 1: 4$ & 1.5 & 1. 7 & (x) & - & $\ldots$ & $\ldots$ & 4.1 & 3.4 & 2.6 & 2.1 & 1.5 & -- & - & -. & -- & -. & $\ldots$ & - & -. & -. & $\therefore$ \\
\hline
\end{tabular}

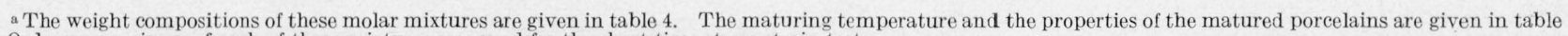

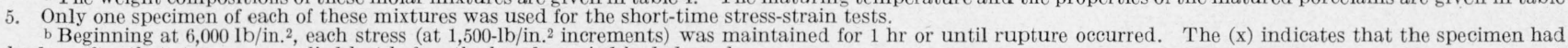
broken after that stress was applied but before the hourly period had elapsed. 
tetragonal to monoclinic transformation and the known high expansion of tetragonal zirconia (coefficient of 12 to $13.5 \times 10^{-6}$ ) [22] are considered to have been of sufficient magnitude to have caused the physical deterioration of the samples. Because of the limited time available to this project, no attempts were made to eliminate these conditions by transforming the zirconia to the stable cubic form by the addition of $\mathrm{CaO}$.

Except for mixtures $2 \mathrm{~B}: 1 \mathrm{Ce}: 2 \mathrm{Z}$ and $4 \mathrm{~B}: 1 \mathrm{Ce}: 8 \mathrm{Z}$, all of those studied showed varying reduction of $\mathrm{CeO}_{2}$. Usually, this could be seen only when the interior of a specimen was examined. However, it is well known that very small amounts of $\mathrm{Ce}_{2} \mathrm{O}_{3}$ (less than $0.01 \%$ ) have extremely strong coloring effects. The amount of reduction in these samples is considered as being very small because no evidence of $\mathrm{Ce}_{2} \mathrm{O}_{3}$ could be found by petrographic or $\mathrm{X}$-ray analyses.

Table 6 gives the results of the short-time $(1 \mathrm{hr})$ stress-strain tests at $1,800^{\circ} \mathrm{F}$. for some of these porcelains and their interval-strain rates under 6,000-, 12,000-, and 15,000-lb/in. ${ }^{2}$ stress for 5-, 10-, $20-, 30-$, and $60-\mathrm{min}$ intervals. At $12,000-\mathrm{lb} / \mathrm{in}^{2}$ stress, the strain rates for these $\mathrm{BeO}-\mathrm{CeO}_{2}-\mathrm{ZrO}_{2}$ poreclains were rather low, about $1.5 \times 10^{-6}$ (in./in.)/ min, and were very similar to those of the BeO$\mathrm{Al}_{2} \mathrm{O}_{3}-\mathrm{TiO}_{2}$ porcelains [4].

\section{The System $\mathrm{BeO}-\mathrm{Cr}_{2} \mathrm{O}_{3}-\mathrm{ZrO}_{2}$}

\subsection{Phase Relations}

\section{a. The System $\mathrm{BeO}-\mathrm{Cr}_{2} \mathrm{O}_{3}$}

Minimum melting at about 30 weight percent of $\mathrm{BeO}$ and $2,230^{\circ} \mathrm{C}$ has been reported [6] for this system. Although $\mathrm{BeO}+\mathrm{Cr}_{2} \mathrm{O}_{3}$ mixtures were not investigated in the present study, the compound beryllium chromate $\left(\mathrm{BeO} \cdot \mathrm{Cr}_{2} \mathrm{O}_{3}\right)$, the chromia analog of chrysoberyl ( $\mathrm{BeO} \cdot \mathrm{Al}_{2} \mathrm{O}_{3}$ ), was identified in most of the $\mathrm{BeO}-\mathrm{Cr}_{2} \mathrm{O}_{3}-\mathrm{ZrO}_{2}$ mixtures heated at $1,800^{\circ} \mathrm{C}$ (see section 5.2).

It was found that this orthorhombic compound is isostructural with chrysoberyl and has the following approximate crystallographic parameters: $a=10.0 \mathrm{~A}$, $b=5.8 \mathrm{~A}, c=4.5 \mathrm{~A}$, as compared to those of chrysoberyl: $a=9.39 \mathrm{~A}, b=5.47 \mathrm{~A}$, and $c=4.24 \mathrm{~A}$. No attempts were made to synthesize the pure compound.

\section{b. The System $\mathrm{BeO}-\mathrm{ZrO}_{2}$}

The equilibria are described in section 3.1, b.

$$
\text { c. The System } \mathrm{Cr}_{2} \mathrm{O}_{3}-\mathrm{ZrO}_{2}
$$

A rather flat and long minimum melting region at about 30 to 60 weight percent of $\mathrm{ZrO}_{2}$ and about $2,320^{\circ} \mathrm{C}$ has been reported for this system [9].

\section{d. The System $\mathrm{BeO}-\mathrm{Cr}_{2} \mathrm{O}_{3}-\mathrm{ZrO}_{2}$}

No literature references could be found describing the phase relations for the beryllia-chromia-zirconia system. In this investigation, an X-ray examination was made, using an interior surface of each mixture heated at $1,800^{\circ} \mathrm{C}$. The compositions studied are located within the subordinate ternary system
$\mathrm{BeO}-\mathrm{BeO} \cdot \mathrm{Cr}_{2} \mathrm{O}_{3}-\mathrm{ZrO}_{2}$. Beryllia, monoclinic zirconia, and beryllium chromate are found in all mixtures except $1 \mathrm{~B}: 1 \mathrm{Cr}: 1 \mathrm{Z}$ and $4 \mathrm{~B}: 4 \mathrm{Cr}: 1 \mathrm{Z}$. In these, only monocline zirconia and $\mathrm{BeO} \cdot \mathrm{Cr}_{2} \mathrm{O}_{3}$ are present. There are no apparent solid solutions formed between any binary or ternary combination of beryllia, monoclinic zirconia, and beryllium chromate, and there are no known ternary compounds.

Figure 4 shows a possible liquidus surface configuration for this system based upon extremely limited data and a considerable amount of speculation. The compound $\mathrm{BeO} \cdot \mathrm{Cr}_{2} \mathrm{O}_{3}$ should melt congruently if it is assumed that the $\mathrm{BeO}-\mathrm{Cr}_{2} \mathrm{O}_{3}$ system contains approximately the same equilibria relations as are present in the $\mathrm{BeO}-\mathrm{Al}_{2} \mathrm{O}_{3}$ [4] system. $\mathrm{By}$ a similar analogy the compound $\mathrm{BeO} \cdot 3 \mathrm{Cr}_{2} \mathrm{O}_{3}$ also may be present and may melt congruently. It seems reasonable to assume, from previous work on pure-oxide systems $[1,2,3,4]$, that the lowest melting invariant point in this system should be about 150 to $200 \mathrm{deg} \mathrm{C}$ above the lowest maturing-range temperature; i. e., at about $2,000^{\circ} \mathrm{C}$ (see section 5.2 for maturing data).

\subsection{Ceramic Bodies}

Reports of the volatility of $\mathrm{Cr}_{2} \mathrm{O}_{3}$ in binary mixtures $[6,9]$ indicate that it occurs at temperatures of approximately $2,000^{\circ} \mathrm{C}$ or higher, except when binary invariant points occur at lower temperatures. In this investigation it was found that an appreciable amount of $\mathrm{Cr}_{2} \mathrm{O}_{3}$ was lost from the specimens at temperatures as low as $1,600^{\circ}$ to $1,700^{\circ} \mathrm{C}$. This occurred on all exposed specimen surfaces, as evidenced by the relatively light surface color as compared to the dark interior color. In addition, recrystallized $\mathrm{Cr}_{2} \mathrm{O}_{3}$ was found as dark-green or green-gray contamination areas in various portions of the furnace refractories.

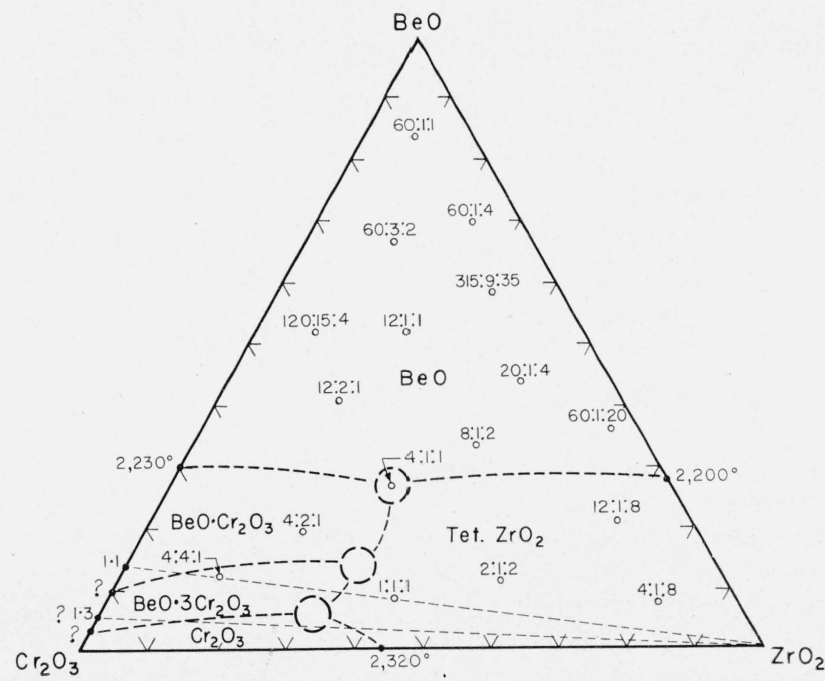

Figure 4. Possible equilibria relations for the $\mathrm{BeO}-\mathrm{Cr}_{2} \mathrm{O}_{3}-$ $\mathrm{ZrO}_{2}$ system.

The equilibria of this system are based upon extremely limited data and a considerable amount of speculation. Beryllium chromate $\left(\mathrm{BeO} . \mathrm{Cr}_{2} \mathrm{O}_{3}\right)$, the chromia siderable amount of speculation. Beryllium chromate $\left(\mathrm{BeO} . \mathrm{Cr}_{2} \mathrm{O}_{3}\right)$, the chromia
analog of chrysoberyl, was found in all of the mixtures studied. The compositions analog of chrysoberyl, was found in all of the mixtures studied. The compositions
of the mixtures are indicated on the fig tire in molar ratios, but are placed graphiof the mixtures are indicated on the figure in molar ratios, but are placed graphi-
cally according to weight percentages. Mixture $1: 1: 1$ indicates it to be the moleccally according to weight percentages. Mixture $1: 1: 1$ indicates it to be the molec-
ular ratio $1 \mathrm{BeO}: 1 \mathrm{Cr}_{2} \mathrm{O}_{3}: 1 \mathrm{ZrO}_{2}$ and is not intended to infer a compound formuular ratio
lation. 
When heated at $1,800^{\circ} \mathrm{C}$ only two mixtures, $60 \mathrm{~B}: 1 \mathrm{Cr}: 1 \mathrm{Z}$ and $12 \mathrm{~B}: 1 \mathrm{Cr}: 1 \mathrm{Z}$, were found to have matured. Because of the volatilization of the chromia, it was not considered practical to attempt either further heatings at that temperature or higher temperature heatings. The time allotted to the project permitted only one attempt at reducing the maturing temperature. A series of mixtures were prepared that contained an admixture of 2 weight percent of $\mathrm{CaO}$. When the first trials showed that the maturing temperatures were reduced by less than $50 \mathrm{deg} \mathrm{C}$, and that the chromia loss remained appreciable, further work in this system was discontinued.

\section{Discussion}

The principal factors limiting the use of ceramics under stress conditions at temperatures above the useful temperature range for metals are their poor thermal-shock resistance and impact strengths. From a theoretical viewpoint, the resistance to thermal shock may be expressed in the general form.

$$
W \sim \frac{\sigma_{t}}{\alpha E} \cdot F\left(\frac{K t}{\rho C l^{2}}\right),
$$

where $\sigma_{t}$ is the tensile strength, $E$ is Young's modulus, $\alpha$ is the coefficient of linear thermal expansion, $F$ is an unknown function, $K$ is the thermal conductivity, $t$ is the time at which maximum stress is developed, $\rho$ is the density, $C$ is the specific heat, and $l^{2}$ is the dimensional area.

Considering two specimens of the same material and size, one practically impervious and one slightly porous, it can be assumed that the coefficient of linear thermal expansion, Poisson's ratio, and the specific heat will be the same for both, and that for the porous specimen the tensile strength, the thermal conductivity, and the density will be lower. A reduction in Young's modulus with increased porosity is probable for a given body, as shown by the following values for the $1 \mathrm{BeO}: 1 \mathrm{CeO}_{2}: 1 \mathrm{ZrO}_{2}$ mixture:

\begin{tabular}{|c|c|c|c|}
\hline Specimen & Absorption & Bulk density & $\begin{array}{l}\text { Young's } \\
\text { modulus }\end{array}$ \\
\hline $\begin{array}{l}1 \\
2 \\
3 \\
4\end{array}$ & $\begin{array}{r}\% \\
0.00 \\
.23 \\
1.63 \\
1.83\end{array}$ & $\begin{array}{l}\text { g/cm } \\
\text { 5. } 64 \\
\text { 5. } 49 \\
\text { 5. } 33 \\
\text { 5. } 28\end{array}$ & $\begin{array}{l}\quad \text { lb. } \text { in. }^{2} \\
25.7 \times 10^{3} \\
23.6 \\
22.2 \\
22.5\end{array}$ \\
\hline
\end{tabular}

It seems reasonable to expect that the value of the function, $F$, will not be appreciably different for a porous specimen and for a practically impervious specimen. Therefore, the expression $\sigma_{t} / \alpha E$ is the dominant consideration. The conjecture is made that porous oxide porcelains with requisite strength properties may prove of considerable interest in the search for materials of greater thermal-shock resistance than that associated with dense, practically impervious porcelains with high strength properties.

Although most of the mixtures studied in this investigation have fairly good strength properties, both at room temperature and at $1,800^{\circ} \mathrm{F}$, addi- tional work would be required if a considerable number of specimens of any one mixture are desired, all with nearly identical properties. This is illustrated by the variations shown by specimens of mixture $12 \mathrm{~B}: 4 \mathrm{Ti}: 1 \mathrm{Z}$, given in table 2 , when similar samples were fired in the same furnace, at the same apparent temperature, but on different days.

\section{Summary}

\subsection{The System $\mathrm{BeO}-\mathrm{TiO}_{2}-\mathrm{ZrO}_{2}$}

The configuration of the liquidus surfaces indicates the phase equilibrium relations to be those of a simple eutectic system with primary crystallization fields for $\mathrm{BeO}$, tetragonal $\mathrm{ZrO}_{2}, \mathrm{ZrO}_{2} \cdot \mathrm{TiO}_{2}$, and $\mathrm{TiO}_{2}$ solid solutions. The lowest melting ternary mixture studied occurs at about mole ratio $4 \mathrm{BeO}: 4 \mathrm{TiO}_{2}: 1 \mathrm{ZrO}_{z}$ and $1,615^{\circ} \pm 10 \mathrm{deg}$. C.

Those mixtures whose compositions are within the triangular area bounded by $\mathrm{BeO}, \mathrm{ZrO}_{2} \cdot \mathrm{TiO}_{2}$, and $\mathrm{TiO}_{2}$, and which contain at least 15 to 20 weight percent of $\mathrm{BeO}$, could be matured to imperviousness. but only when the sample size was small $(5 / 8$ in. in diameter by $1 / 2$ in. high). Considerable difficulty was encountered in fabricating large, usable samples (6 in. long by $3 / 4$ in. wide by $5 / 16$ in. thick) probably because of the length change, parallel to the $c$-axis, that occurs during the crystallographic transformation of $\mathrm{ZrO}_{2} \cdot \mathrm{TiO}_{2}$ between $800^{\circ}$ and $1,200^{\circ} \mathrm{C}$. Some usable test specimens could be made when 2 weight percent of $\mathrm{CaO}$ was added to the base mixtures. The range of physical property values for the BeC$\mathrm{TiO}_{2}-\mathrm{ZrO}_{2}$ porcelains investigated is given in table 7 .

\subsection{The system $\mathrm{BeO}-\mathrm{CeO}_{2}-\mathrm{ZrO}_{2}$}

The limited data available indicates this to be a simple system with primary crystallization fields of $\mathrm{BeO}$, tetragonal $\mathrm{ZrO}_{2}$ solid solution, and $\mathrm{CeO}_{2}$ solid solution. No liquidus surface equilibrium diagram is given because the lowest melting invariant point was not located at a composition consistent with the phase rule. The data indicate that the invariant point temperature is at least as high as $1,845^{\circ} \mathrm{C}$.

All of the mixtures studied, except those few near the reported $\mathrm{BeO}-\mathrm{ZrO}_{2}$ and the $\mathrm{CeO}_{2}-\mathrm{ZrO}_{2}$ eutectic compositions, could be matured to imperviousness, but only when a small specimen was used. Large, strength-test samples were difficult to obtain in usable form probably because of the large expansion of tetragonal zirconia and, for some samples, because of the crystallographic transformation of tetragonal zirconia to the monoclinic form during cooling. The range of physical property values for the $\mathrm{BeO}$ $\mathrm{CeO}_{2}-\mathrm{ZrO} \mathrm{O}_{2}$ porcelains investigated is given in table 7 .

\subsection{The system $\mathrm{BeO}-\mathrm{Cr}_{2} \mathrm{O}_{3}-\mathrm{ZrO}_{2}$}

Although the binary system $\mathrm{BeO}-\mathrm{Cr}_{2} \mathrm{O}_{3}$ was not studied, beryllium chromate $\left(\mathrm{BeO} \cdot \mathrm{Cr}_{2} \mathrm{O}_{3}\right)$, the chromia analog of chrysoberyl, was identified in all of the ternary mixtures. The crystallographic parameters of this orthorhombic compound are tentatively given as being $a=10.0 \mathrm{~A}, b=5.8 \mathrm{~A}$, and $c=4.5$ A. The compositions studied ara located within 
TARLE 7. Summary and comparison of the physical properties of some $\mathrm{BeO}-\mathrm{TiO}_{2}-\mathrm{ZrO}_{2}$ and $\mathrm{BeO}_{-} \mathrm{CeO}_{2}-\mathrm{ZrO}_{2}$ porcelains

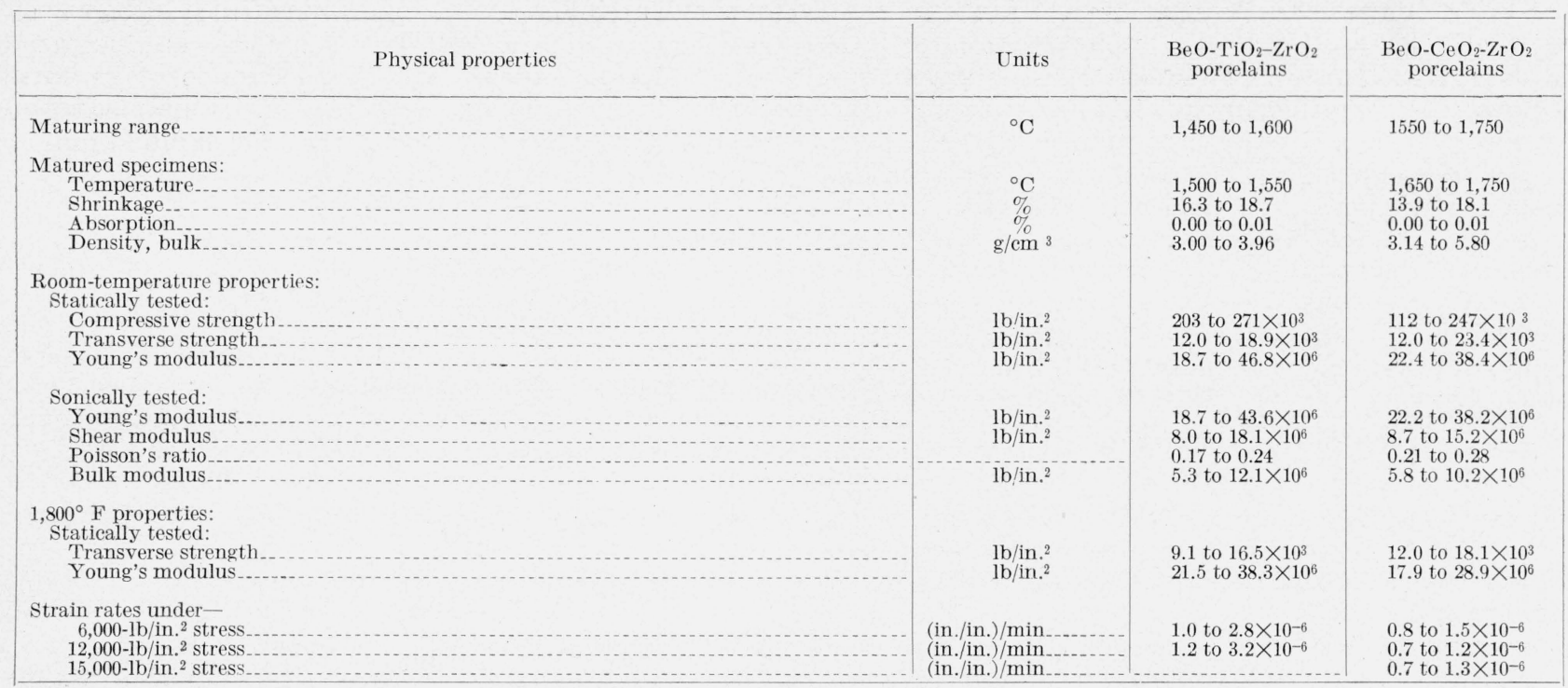

the subordinate ternary system $\mathrm{BeO}-\mathrm{BeO} \cdot \mathrm{Cr}_{2} \mathrm{O}_{3}-\mathrm{ZrO}_{2}$.

Based upon extremely limited data and a considerable amount of speculation, it is suggested that the $\mathrm{BeO}-\mathrm{Cr}_{2} \mathrm{O}_{3}-\mathrm{ZrO}_{2}$ equilibrium diagram should contain three invariant points, each above $2,000^{\circ} \mathrm{C}$, with primary crystallization fields for $\mathrm{BeO}$, tetragonal $\mathrm{ZrO}_{2}, \mathrm{BeO} \cdot \mathrm{Cr}_{2} \mathrm{O}_{3}, \mathrm{BeO} \cdot 3 \mathrm{Cr}_{2} \mathrm{O}_{3}$, and $\mathrm{Cr}_{2} \mathrm{O}_{3}$.

Only two ternary mixtures attained an impervious structure when heated as high as $1,800^{\circ} \mathrm{C}$ for 1 hour. An admixture of 2 weight percent of lime, $\mathrm{CaO}$, to some of these resulted in only a slight lowering of the maturing temperatures and no noticeable reduction of the chromia losses. Because of these appreciable chromia losses, no work was done to fabricate test specimens.

\subsection{General Considerations}

Of possible interest to the designers of hightemperature components are the room-temperature elastic properties (Young's modulus, shear modulus, Poisson's ratio, and bulk modulus) that are presented, it is believed for the first time, for a series of porcelain-type ceramics. It should be noted that the commonly accepted value of Poisson's ratio (0.30) for oxide porcelains is considerably higher than those determined for the $\mathrm{BeO}-\mathrm{TiO}_{2}-\mathrm{ZrO}_{2}$ and $\mathrm{BeO}-\mathrm{CeO}_{2}-\mathrm{ZrO}_{2}$ porcelains.

One of the more interesting sidelights of the investigation is the suggestion that porous oxide porcelains with requisite strength properties may prove of considerable interest in the search for materials of greater thermal-shock resistance than that associated with dense, practically impervious oxide porcelains with high-strength properties.

The authors express their appreciation to the late R. E. Moreland, who performed many of the physical property tests after fabricating many of the specimens; to S. Spinner, for the sonic testing; and to R. F. Geller, who outlined the original program.

\section{References}

[1] R. F. Geller, P. J. Yavorsky, B. L. Steierman, and A. S. Creamer, J. Research NBS 36, 277 (1946) RP1703.

[2] S. M. Lang, L. H. Maxwell, and R. F. Geller, J. Research NBS 43, 429 (1949) RP2034.

[3] S. M. Lang, L. H. Maxwell, and M. D. Burdick, J. Research NBS 45, 366 (1950) RP2147.

[4] S. M. Lang, C. L. Fillmore, and L. H. Maxwell, J. Research NBS 48, 298 (1952). RP2316.

[5] S. Spinner, J. Am. Ceram. Soc. 37, 229 (1954).

[6] H. von Wartenberg, H. J. Reusch, and E. Saran, Z. anorg. u. allgem. Chem. 230, 257 (1937).

[7] E. C. Henry, Pennsylvania State College, Quarterly Progress Report, Memorandum Report No. 19 (Feb. $15,1949)$

[8] O. Ruff, F. Ebert, and E. Stephan, Z. anorg. u. allgem. Chem. 180, 221 (1929).

[9] H. von Wartenberg and H. Werth, Z. anorg. u. allgem. Chem. 190, 178 (1930).

[10] H. von Wartenberg and W. Gurr, Z. anorg. u. allgem. Chem. 196, 374 (1931)

[11] O. Ruff, F. Ebert, and H. von Wartenberg, Z. anorg. u. allgem. Chem. 196, 335 (1931).

[12] H. von Wartenberg and H. Werth, Z. anorg. u. allgem. Chem. 213, 321 (1933).

[13] E. Ryschkewitsch, Chem. App. 24, 137 (1937.).

[14] W. Bussem, C. Schusterius, and A. Ungewiss, Ber. duet. keram. Ges. 18, 433 (1937).

[15] H. G. Sowman and A. I. Andrews, J. Am. Ceram. Soc. 34, 298 (1951).

[16] Personal communication from H. G. Sowman to R. S. Roth.

[17] F. H. Brown and P. Duwez, Jet Propulsion Lab., California Institute of Technology, Prog. Rept. No. 20-180 (Aug. 20, 1952)

[18] F. H. Brown and P. Duwez, J. Àm. Ceram. Soc. 37, 129 (1954).

[19] L. W. Coughanour, R. S. Roth and V. A. DeProsse, J. Research NBS 52, 37 (1954) RP2470.

[20] H. von Wartenberg and K. Eckhardt, Z. anorg. u. allgem. Chem. 232, 179 (1937).

[21] O. Ruff and F. Ebert, Z. anorg. u. allgem. Chem. 180, 19 (1929).

[22] R. F. Geller and P. J. Yavorsky, J. Research NBS 35, 87 (1945) RP1662.

[23] C. E. Curtis, J. Ám. Ceram. Soc. 30, 180 (1947).

[24] P. Duwez and F. Odell, J. Am. Ceram Soc. 33, 274 (1950).

[25] O. Ruff, F. Ebert, and W. Loerpabel, Z. anorg. u. allgem. Chem. 207, 310 (1932).

Washington, May 25, 1954 